Deep Sea Research Part II: Topical Studies in Oceanography FEB 2005; 52(3-4) : 545-564

http://dx.doi.org/10.1016/j.dsr2.2004.12.006

(c) 2005 Elsevier Ltd All rights reserved
Archimer, archive institutionnelle de l'Ifremer http://www.ifremer.fr/docelec/

\title{
Lagrangian circulation of Antarctic Intermediate Water in the subtropical South Atlantic
}

\author{
Ismael Núñez-Riboni ${ }^{\mathrm{a}, *}$, Olaf Boebel ${ }^{\mathrm{a}}$, Michel Ollitrault ${ }^{\mathrm{b}}$, Yuzhu You $^{\mathrm{c}}$, \\ Philip L. Richardson ${ }^{d}$ and Russ Davis ${ }^{\mathrm{e}}$
}

\footnotetext{
${ }^{a}$ Alfred Wegener Institute for Polar and Marine Research (AWI), Bussestraße 24, 27570 Bremerhaven, Germany ${ }^{b}$ Institut Français de Recherche pour l'Exploitation de la Mer (IFREMER), Centre de Brest, BP 70, 29280 Plouzane, France

${ }^{\mathrm{c}}$ The University of Sydney Institute of Marine Science (USIMS), Edgeworth David Building F05, University of Sydney, NSW 2006, Australia

d Woods Hole Oceanographic Institution (WHOI), Woods Hole, MA 02543, USA

${ }^{\text {e }}$ Scripps Institution of Oceanography (SIO), UCSD, 9500 Gilman Drive, La Jolla, CA 92093-0230, USA

*: Corresponding author : Tel.:+49 4714831 1877; fax: +49 4714831 1797; nunez@awi-bremerhaven.de
}

\begin{abstract}
:
This study combines float data from different projects collected between 1991 and 2003 in the South Atlantic to describe the flow of Antarctic Intermediate Water (AAIW). Velocity space-time averages are calculated for various grid resolutions and with cells deformed to match the bathymetry, $f / H$ or $f / h$ (with $H$ being the water depth and $h$ being the thickness of the AAIW layer). When judged by the degree of alignment between respective isolines and the resulting average velocity fields, the best grid is based on a nominal cell size of $3^{\circ}$ (latitude) by $4^{\circ}$ (longitude) with cell shapes deformed according to $\mathrm{f} / \mathrm{h}$. Using this grid, objectively estimated mean currents (and their associated errors), as well as meridional and zonal volume transports are estimated. Results show an anticyclonic Subtropical Gyre centred near $36^{\circ} \mathrm{S}$ and spanning from $23 \pm 1^{\circ} \mathrm{S}$ to $46 \pm 1^{\circ} \mathrm{S}$. The South Atlantic Current meanders from $33^{\circ} \mathrm{S}$ to $46^{\circ} \mathrm{S}$ and shows a mean speed of $9.6 \pm 7.8 \mathrm{~cm} \mathrm{~s}^{-1}\left(8.5 \pm 3.5 \mathrm{~Sv} ; 1 \mathrm{~Sv}=1 \times 10^{6} \mathrm{~m}^{3} \mathrm{~s}^{-1}\right)$. The northern branch of the Subtropical Gyre is located between $22^{\circ} \mathrm{S}$ and $32^{\circ} \mathrm{S}$ and flows westward with a mean speed of $4.7 \pm 3.3 \mathrm{~cm} \mathrm{~s}^{-1}(9.3 \pm 3.4 \mathrm{~Sv})$. Evidence of a cyclonic Tropical Gyre divided in two subcells is visible on the stream function.
\end{abstract}

Keywords: Antarctic Intermediate Water (AAIW), floats, neutral density surfaces, South Atlantic, Lagrangian circulation, transports, objective analysis. 


\section{Introduction}

During the late 20's of the last century, Deacon (1933) and Wüst (1935) first recognized Antarctic Intermediate Water (AAIW) throughout the South Atlantic by virtue of its mid-depth vertical salinity minimum, building on early studies of Buchanan (1877) and

5 Brennecke (1921). Since then, the presence of AAIW has been documented in all three world oceans, with its freshest variety $(S \approx 34.2)$ observable in the South Atlantic, directly north of the Subantarctic Front (SAF), where the salinity minimum outcrops. Throughout the subtropical South Atlantic, AAIW occupies the depth range from 650 to 1050 meters (Reid, 1994), with typical temperature and salinity values of $3^{\circ} \mathrm{C}$ and 34.3 , respectively (Tomczak

10 and Godfrey, 1994). AAIW spreads across the equator and traces thereof can be found as far north as $30^{\circ} \mathrm{N}$ in the North Atlantic (Talley, 1996; Figure 1 below). In the Indian Ocean, AAIW reaches the Bay of Bengal (You, 1998), whereas in the Pacific it does not extend past the equator (Tomczak and Godfrey, 1994).

In the subtropical South Atlantic, based on hydrographic measurements, Deacon

15 (1933) and Wüst (1935) suggested a basin wide, sluggish northward flow of AAIW, with Wüst (1935) additionally proposing a slightly intensified flow along the Brazilian shelf for latitudes lower than $20^{\circ} \mathrm{S}$. Subsequent geostrophic calculations (Defant, 1941) suggested a continuous northward flow along the western boundary from $30^{\circ} \mathrm{S}$ to the equator and beyond, while retaining significant interior northward currents for the region south of $25^{\circ} \mathrm{S}$. More recently, estimates based on the geostrophic method (Reid, 1989; Gordon and Bosley, 1991; Suga and Talley, 1995; Talley, 1996), replaced this concept of a basin wide northward flow by a succession of two basin scale, zonally stretched gyres: the anticyclonic Subtropical Gyre centred at $34^{\circ} \mathrm{S}$ and the cyclonic Tropical Gyre (Gordon and Bosley, 1991) centred at about $10-15^{\circ} \mathrm{S}$ (See Figure 2). Further refinements within these gyres have been suggested by Suga and Talley (1995). They argued that three smaller gyres reside within the Tropical Gyre (Suga and Talley call it Subequatorial Gyre): two cyclonic cells at the northern and southern limits 
of the gyre, and an anticyclonic cell in between (centred at about $13^{\circ} \mathrm{S}$ ). However, the appropriateness of the concepts of a Tropical Gyre as such and of nested multi-gyres within remains obscure. Similarly, the strengths of the gyres' interactions, either during the water's cross-basin advection or when encountering ocean margins, are poorly known. These

5 shortcomings are primarily based on the scarceness of data from the South Atlantic and the resulting questionable representativeness of single hydrographic sections, as well as on the familiar problem of choosing an appropriate reference layer for geostrophic velocity estimates.

Recent technological advances have enabled us to obtain direct velocity measurements not only at selected sites, but over vast oceanic regions of the South Atlantic, using neutrally buoyant, freely drifting floats (Rossby et al., 1986; Davis et al., 1992). A combination of these Lagrangian with geostrophic and Eulerian current measurements resulted in the generally accepted, overall flow pattern: The South Atlantic Current (Stramma and Peterson, 1990), resulting from the merging of the Malvinas/Falkland and Brazil currents in the Confluence

15 Zone, flows eastward across the Argentine Basin and Mid-Atlantic Ridge before it interacts with waters from the Indian Ocean in the Cape Basin. There, strong eddy activities result in a mixture of South Atlantic and Indian Ocean waters, which leaves the region to the northwest across the Walvis Ridge. Thereby, flow in the intermediate depth layer of what commonly is termed Benguela Current (Stramma and Peterson, 1989; Richardson and Garzoli, 2003)

20 eventually turns west, forming the northern branch of the Subtropical Gyre or Benguela Current Extension (Richardson and Garzoli, 2003).

After passing the Mid-Atlantic Ridge, the intermediate water finally reaches the South American coast where it splits in two branches at the Santos Bifurcation (Boebel, et al., 1999a). One branch is a narrow northward intermediate western boundary current (IWBC)

25 (counter to the northern Brazil Current flowing southward near the surface), carrying AAIW to the tropics and eventually to the equatorial region. There, a series of alternating jets are 
hypothesised to facilitate the cross-equatorial transfer between $5^{\circ} \mathrm{S}$ and $5^{\circ} \mathrm{N}$ (Boebel et al., 1999a and c; Schmid et al., 2001; Molinari, 1981; Reid, 1996; Talley, 1996, Ollitrault, 1994 and 1999; Richardson and Schmitz, 1993; Jochum and Manalotte-Rizzoli, 2003, Schmid et al., 2005). The other branch deriving from the Santos Bifurcation is a south-westward flowing current, forming a deep extension of the southern Brazil Current, which ultimately closes the Subtropical Gyre. This limb carries recirculated AAIW into the Confluence Zone, where it is mixed with freshly formed AAIW from the Subantarctic Front, resulting in waters to be again entrained into the Subtropical Gyre (Boebel et al., 1999b).

The main goal of the study at hand is to provide a comprehensive analysis of the motion of AAIW throughout the entire subtropical South Atlantic as based on Lagrangian direct velocity measurements. To this end we collected float data from historic and contemporary Lagrangian programs, compiling South Atlantic float data from more than a decade. From this data set, we computed space-time averages and objectively mapped fields of velocity, as well as volume transports for the AAIW layer. subjectively the details of the underlying spatial grid on which such calculations are based. However, to obtain the optimum balance between spatial resolution and statistical robustness, the choice of an adequate spatial grid is of a vital importance: a coarse resolution yields currents structures that lack spatial resolution while a resolution too fine may yield average currents contaminated with mesoscale processes. An extreme illustration of the first situation would by the hypothetical merging of opposing currents through an unfortunate grid choice, leading to their mutual cancellation, while in the second situation a single transient eddy could be interpreted as a permanent recirculation cell. Here we propose an objective method to choose a "best" spatial averaging grid, producing the abovementioned space-time averages of velocity. These calculations are followed by objective mapping (OM) of the resulting velocity 
map, using selected "best" OM parameters, i.e. optimized choices for the error of the climatological field and the spatial correlation length.

Finally, the selection of vertical boundaries of the AAIW layer by potential density or isobaric surfaces, as executed in previous studies, directly influences the soundness of these

5 results. Potential density is a poor proxy of the vertical structure of the AAIW layer, especially when using a unique isopycnal surface, while isobaric surfaces fare even worse. Therefore we constrained the AAIW layer by neutral density (or isoneutral) surfaces (McDougall, 1987), which aptly approximate the vertical structure of the layer (You, 2002; You et al., 2003). However, for comparison, we also estimate and discuss the flow field as constrained by isobaric surfaces.

\section{Data description}

This study is based on float trajectory and hydrographic data. The first type of data provided us with direct Lagrangian current measurements within the intermediate depth layer. The latter were used to construct isoneutral surfaces to constrain the AAIW layer in order to select the float's data in the vertical. This hydrographic data was also used to (tentatively) calculate geostrophic shear within the AAIW layer, to project the float velocities onto the central neutral surface.

\subsection{Float Data}

Floats are neutrally buoyant devices that drift freely at depth. Consequently, even weak oceanic subsurface currents are captured by the floats' paths (see Gould, 2005). Float trajectories can be established by either recording satellite fixes when floats surface at preprogrammed intervals (ALACE and APEX floats, Davis et al., 1992) or via triangulation of times of arrival of coded sound signals (SOFAR floats, Rossby and Webb, 1970; RAFOS floats, Rossby et al., 1986; MARVOR floats, Ollitrault et al., 1994). Floats located by means of satellite fixes must ascend periodically to the surface to transmit their data, which is why 
they are frequently called pop-up floats. Pop-up float positions are determined at intervals ranging from one to two weeks. With these floats rising to the surface for positioning, individual float displacements can be considered statistically independent, as unknown geostrophic current-shear and Ekman currents generate a decorrelation between ascent and

5 descent positions. Hence, the "trajectory" of a pop-up float is, by itself, of little relevance, and is named hereinafter "sequence of displacements". Acoustically tracked floats, by contrast, do not ascend to the surface and follow by and large -at least in regions void of fronts- their surrounding water parcels. This renders their trajectories meaningful in a quasi-Lagrangian sense (Rossby et al., 1985).

We selected float data inside the region bounded by the $4^{\circ} \mathrm{S}$ and $70^{\circ} \mathrm{S}$ parallels and by the $70^{\circ} \mathrm{W}$ and $30^{\circ} \mathrm{E}$ meridians. Floats with any part of their sequence of displacements inside this box are included in Table 1. However, the data set used in the analysis, as well as the calculation of the number of float-years (Table 1), includes float displacements within the box only. The entire float data set comprises 451 float years including 38 APEX floats from 15 Alfred Wegener Institute (AWI), 19 of which co-join the Argo project, 60 APEX floats from the Argo project (in addition to the 19 AWI floats), 42 ALACE and PALACE floats from the WOCE (World Ocean Circulation Experiment) and CORC (Consortium on the Ocean's Role in Climate) programmes, 101 RAFOS floats of the KAPEX (Cape of Good Hope Experiment), 74 MARVOR floats from the SAMBA (SubAntarctic Motions in the Brazil Basin) experiment, including all SAMBA1 and SAMBA2 data and 71 RAFOS floats from the WOCE/DBE (See Table 1 for references and explanation of acronyms of float types).

Most of the pop-up floats cycled every 10 days, except for some AWI floats, which cycled every 7 days. Occasionally, subsurface displacements lasted longer than 10 days, probably due to either poor satellite fixes preventing the determination of the float's position at the surface (e.g. due to high sea-state) or the float's failure to ascend and transmit data (e.g. due to sea-ice at high latitudes). Both situations lead to an unknown contamination of the 
displacement vector with surface drifts. All acoustically tracked floats recorded arrival times of coded sound signals at least once daily.

To generate a statistically consistent data set, we matched the periods of underwater drift between various float types: For pop-up floats, we maintained their inherent drift period 5 of 7 to 10 days; longer displacement periods were rejected due to the possible contaminations mentioned above. For acoustic floats we simulated the pop-up-float behaviour (Richardson, 1992) by subsampling the trajectories at a ten-day cycle, resulting in a sequence of float positions every 10 days.

From the ensuing data set of float positions, the floats' underwater displacement-

10 vectors were calculated with the first and last satellite's fixes (pop-up floats) or underwater position (acoustic floats) for each 7-10 day cycle. Velocities were calculated by dividing each underwater displacement-vector by its corresponding exact duration (about 10 days). Each velocity vector was assigned to the midway position between the start and end positions of the displacement-vector. Finally, velocities were quality checked by searching for velocities 15 higher than $2 \mathrm{~m} \mathrm{~s}^{-1}$; no such value occurred.

As discussed above, pop-up float displacement-vectors can be considered inherently independent from each other due to drifts during their ascent, descent and surface phases. However, 10-day displacements from acoustically tracked floats can only be considered statistically independent, because the integral Lagrangian time scale has been shown to be 20 equal or shorter than 10 days throughout the region and depth horizon considered here (Boebel et al, 1999c).

To extract the AAIW layer flow, float data was selected in the vertical according to three alternative schemes: two based on isoneutral surfaces and one based on isobaric surfaces (650 to 1050 dbar, following Boebel et al., 1999a). The hydrographic data base for 25 these selections is described in the following section. 


\subsection{Vertical data selection}

For the proper description and quantification of the AAIW's circulation, an appropriate definition of its vertical extent is of central importance. Salt and heat fluxes from the water layers above and below, as well as mixing with waters from the Indian Ocean render

5 isohalines and isotherms inappropriate as layer boundaries. Potential density surfaces, on the other hand, inadequately describe the vertical position of water masses without being referred to different pressure values. For example north of $5^{\circ} \mathrm{S}$ the surface of minimum salinity resides at a deeper depth than the isopycnal surface that best describes the AAIW layer at southern latitudes (Figure 1). Therefore, the AAIW core, when defined by its salinity minimum, can not be tracked by a single potential density surface.

Neutral density surfaces have been shown to suitably describe the AAIW salinity minimum in the South Atlantic (You, 1999). For this reason, this paper uses gridded isoneutral surfaces of $1^{\circ} \times 1^{\circ}$ resolution at the core $\left(\gamma^{\mathrm{n}}=27.40\right)$, upper $\left(\gamma^{\mathrm{n}}=27.25\right)$ and lower boundaries $\left(\gamma^{\mathrm{n}}=27.55\right)$ of the AAIW layer, using data from You (2002) (3311 stations covering 70W-30E, 80S-0) and You et al. (2003) (5684 stations covering 10W-50E, 50S20S). Two additional isoneutral surfaces $\left(\gamma^{\mathrm{n}}=27.32\right.$ and $\left.\gamma^{\mathrm{n}}=27.45\right)$ were calculated between the upper boundary and the core, as well as between the core and the lower boundary to provide further information on the vertical structure of the AAIW layer. The layer between these upper and lower isoneutral surface is called "isoneutral layer" hereinafter.

Based on the depths of these surfaces in comparison with the average float pressure during the displacement period, float displacement vectors were selected in the vertical (Figure 3, step 1). The primary data set was obtained by accepting only those float displacement vectors residing at depths within the AAIW layer as defined by the isoneutral layer, which maintained $68 \%$ of the original data. For comparison, additional data sets were obtained by either selecting according to isobaric surfaces or shifted isoneutral surfaces. For the latter, the upper and lower neutral surfaces were displaced by moving those surfaces $50 \mathrm{~m}$ 
up and down, respectively. This resulted in a $100 \mathrm{~m}$ thicker AAIW layer (called expanded isoneutral layer hereinafter) and an increased rate of accepted displacement vectors of $73 \%$. The isobaric layer contained float displacements located between 650 and $1050 \mathrm{dbar}(93 \%$ of the original data) as used in Boebel et al. (1999a). In the following we will mainly focus on

5 the data set within the isoneutral layer, and leave the comparison with the other data sets to the final discussion.

\subsection{Geostrophic projection - a test}

To test the influence of geostrophic shear within the AAIW layer on our results, the original 10-day displacement vectors were corrected using geostrophic velocity shear profiles, following the concepts employed by Gille (2003) and Richardson and Garzoli (2003) (see Figure 3, step 2). The velocities projected onto the AAIW's core differed only marginally from the original measures (on the order of $0.01 \mathrm{~cm} \mathrm{~s}^{-1}$ ). These deviations yielded no detectable difference between space-time average maps, objective maps or transports and, hence, modifications due to the projection are ignored hereinafter.

\section{Analysis}

\subsection{Space-time average}

Space-time averages were obtained by binning float velocity vectors according to their effective distance to the nodes of a regular grid (Figure 3, step 3). The effective distance between velocity vector and nodes was measured according to the norm developed by Davis $(1998 \text {, his equation } 9)^{1}$, and each velocity vector was assigned to the node closest under this norm:

$$
r^{2}=\left|\vec{x}_{a}-\vec{x}_{b}\right|^{2}+\left[3 \mu \frac{H_{a}-H_{b}}{H_{a}+H_{b}}\right]^{2} \quad ; \quad \mu \geq 0
$$

\footnotetext{
${ }^{1}$ What we show here is the equation as actually used by Davis (1998). The equation as displayed in Davis (1998) features a variable 'L' from an alternative version (Davis, 2003, personal communication).
} 
where $\vec{x}_{a}$ is the position vector of the centre of a given cell, $H_{a}$ the local smoothed water depth, and $\vec{x}_{b}$ is the position vector of the centre of a given float displacement (where the water depth reads $H_{b}$ ). The first term in equation (1) is the horizontal distance among vectors $\vec{x}_{a}$ and $\vec{x}_{b}$, whereas the second term is the normalized depth-difference among these two

5 points (multiplied by an arbitrary weight $3 \mu$ ). The minimization of $r$ corresponds to a joint minimization of the horizontal distance and the depth-difference among $\vec{x}_{a}$ and $\vec{x}_{b}$. Application of equation (1) to a regular grid leads to a stretching of the rectangular cells around each node along isobaths. Underlying to this approach is the idea that currents tend to more likely follow isobaths than to cross them, as exemplified in the extreme case of boundary currents. The net effect of the procedure is illustrated in Figure 4, where every possible position of a $3^{\circ}$ by $4^{\circ}$ grid is assigned to the respective closest node. Here, rather than bathymetry, potential vorticity is used as governing variable (substituting $H$ in equation 1).

The parameter $\mu$ governs the sensitivity of the grid to the bathymetry: growing $\mu$ causes an increased sensitivity of the grid to the bathymetry, while $\mu$ approaching zero causes a grid of increased regularity. The 12 minutes resolution Smith and Sandwell (1997) bathymetry was used herein, and has been smoothed to avoid an undesirable dependence on small scale bathymetric details. Following the study by Gille (2003), a 30 point Hanning filter was applied twice in latitudinal and longitudinal directions, effectively smoothing length scales of less than 1 degree in both directions.

Once binned accordingly, velocity vectors within each cell were averaged (Figure 3, step 4). The resulting space-time averaged velocity vector was positioned at the centre of gravity of the spatial mean of all displacement-vectors within each cell. To ensure robust estimates, mean velocities based on less than 5 data points (i.e. 5 degrees of freedom) were discarded. This is commensurate with Schmid et al., (2001), who argue that -for the equatorial 
region- 30 float-days per box suffice to provide "statistically sound result" (Schmid et al., 2001; page 292).

Space-time averages were calculated for a variety of different cell sizes of the initial regular grid, as well for various values of the parameter $\mu$ (Table 2). Furthermore, the 5 governing variable "bathymetry" was subsequently substituted by potential vorticity of either the entire water column $(f / H)$ or of the AAIW layer $(f / h)$, following LaCasce's (2000) suggestion that the intermediate depth currents of the general circulation predominantly follow isolines of large-scale potential vorticity of the entire water column $(f / H)$.

The various choices of parametric values and governing variables resulted in similar 10 qualitative structures of the averaged current fields, though quantitative differences occurred. Hence a method to objectively determine the grid providing the "best" results is needed. To this end, LaCasce (2000) analysed mean displacements along and across isolines of potential vorticity and dispersions of stochastically modelled floats against time, and performed a statistical study of the tendency of those modelled floats to follow lines of equal potential 15 vorticity. This concept is being followed here in a somewhat simplified approach by calculating an alignment ratio $A$ :

$$
A=\frac{\bar{V}_{\perp}}{\bar{V}_{\|}}=\frac{\sum_{i=1}^{n} V_{\perp}^{i}}{\sum_{i=1}^{n} V_{\|}^{i}},
$$

where $V_{\perp}^{i}$ is the velocity component of the $i^{\text {th }}$ cell perpendicular to the isolines, $V_{\|}^{i}$ is velocity component of the $i^{\text {th }}$ cell parallel to the isolines, and $n$ is the number of averaged velocities 20 involved. This quantity is called alignment number hereinafter. It indicates how well aligned the averaged velocity field is with respect to the isolines: the higher the alignment number, the less aligned the velocity field is, and the smaller the alignment number is, the better aligned the velocity field is. The selection of an objectively "best" grid can then be reduced to finding the grid with the smallest alignment number (Figure 3, step 5). 
We calculated $f / h$ from the thickness $h$ of the AAIW isoneutral layer. To calculate $f / H$, we used the smoothed bathymetry $(H)$ described above. The Coriolis parameter $f=2 \Omega \sin (\lambda)$, was calculated with $\lambda$ being the latitude of the average velocity vector (one per cell).

Performing these calculations at an early stage of this study, the selection of best grid 5 is based only on a subset of the data set described above. However, we assume that sufficient data were available at this time ( $65 \%$ of the actual data set) to ensure an optimum selection of the grid. Results of this selection are shown in Table 2. The first two columns give the dimensions of the original rectangular cells before deformation while column three indicates the value of $\mu$. The next three columns specify the alignment number $A$ (equation 2) as calculated for grids constructed with equation 1 for the three possible governing variables bathymetry, $f / H$ and $f / h$. The minimum value for each governing variable and original grid size is marked in grey. The overall minimum value for each original grid size is denoted in bold letters. From 7 original grid sizes, the minimum alignment number was achieved 5 times for grids deformed according to $f / h$, one time for grids deformed according to $f / H$ and once for a rectangular grid $(\mu=0)$. These results suggest that most appropriate governing variable in equation 1 is $f / h$, and that this physical variable has a bigger influence on the dynamics of the AAIW than $f / H$ or bathymetry. Hence, as basis for our final space-time averages (Figure 3, step 6), we selected an initial regular grid of $3^{\circ}$ in latitude and $4^{\circ}$ in longitude, and we deformed the cells according to $f / h$ with $\mu=6000$.

Finally, 0.63 probability error ellipses were calculated. Due to the statistical independence of all displacement vectors, the number of displacement vectors per cell (Figure 5) enters the calculation directly as number of degrees of freedom. Figure 5 clearly indicates sufficient data coverage throughout the subtropical South Atlantic. For readability, float days are given for original (un-deformed) boxes. The grid after deformation is depicted in Figure 4. 


\subsection{Objective mapping and transport calculations}

Objective mapping is based on the inversion of the covariance matrix of observational values. Due to the available large number of float displacements (approximately 11000 displacements), a direct application of the method to this data set is computationally

5 unfeasable. Rather, the space-time averages described above served as data base for the computation of objectively-mapped velocity and stream-function fields (Hiller and Käse, 1983). The graticule (we will use the word "graticule" for the objective mapping, and "grid" for the space-time averages) was chosen by selecting 1 out of every 8 points of the smoothed bathymetry, yielding a graticule point every $1.6^{\circ}$ in longitude by $1.7^{\circ}$ in latitude (on the average, as the Smith and Sandwell (1997) bathymetry is irregularly spaced in latitude).

Error covariances as assumed in the vectorial OM equal the error estimates of the space-time averages depicted in Figure 6. The "longitudinal covariance function" (Hiller and Käse, 1983) was assumed Gaussian, following the discussion by Hiller and Käse and in lack of alternative estimates. Herein, the climatological error and correlation length of the climatological field define the Gaussian bell's amplitude and width, respectively. To optimise these parameters, we calculated nearly 300 objective velocity maps, using subjectively chosen climatological value pairs (from 3 to $11 \mathrm{~cm} \mathrm{~s}^{-1}$ for the climatologic error and $1^{\circ}$ to $30^{\circ}$ for the correlation length) (Figure 3, step 7). For each resulting velocity map, zonal and meridional volume transports were calculated.

To calculate transport (Figure 9 and step 8 in Figure 3), velocity was considered uniform across the AAIW layer. The local thickness of the AAIW isoneutral layer was calculated by subtracting the depths of the deep boundary $\left(\gamma^{n}=27.55\right)$ from that of the shallow boundary $\left(\gamma^{n}=27.25\right)$. To obtain meridional and zonal transport estimates, velocities were multiplied by the layer's local thickness and the zonal and meridional widths of each graticule cell, respectively. Zonal and meridional transports along or across the basin were 
calculated by summarizing all transports (per cell) along a meridional or zonal section. Zonal sections were calculated coast to coast or to $20^{\circ} \mathrm{E}$ when at latitudes south of Africa.

The errors of the transports associated with each graticule cell $\left(T_{i}^{\prime}\right)$ were calculated using Gauss' law of propagation of errors (Barlow, 1989) from the velocity error estimates provided by the OM and the thickness error of the AAIW isoneutral layer. The latter was assumed as 10 dbar, which equals the maximal depth error of the isoneutral surfaces (Jacket and McDougall, 1997). Error estimates of the mean zonal transport (shaded area in Figure 9) were calculated from each cell's transport error, according to:

$$
\bar{T}^{\prime}=\frac{1}{N_{d f}} \sqrt{\sum_{i=1}^{N} T^{\prime 2}{ }^{2}},
$$

10

where $N$ is the number of cells at a given latitude and $N_{d f}$ is the number of degrees of freedom:

$$
N_{d f}=\frac{N \Delta l}{L}
$$

with $L$ assumed equal to the Lagrangian correlation length ( $4^{\circ}$, see below) and $\Delta l$ equal to the zonal length of the graticule cells.

Estimates of meridional trans-oceanic transports were compatible with values from the literature (Fu, 1981; Roemmich, 1983; Rintoul, 1991; Macdonald, 1993; Matano and Philander, 1993; Holfort, 1994; Saunders and King, 1995; Barnier et al., 1996; Schlitzer, 1996; Speer et al., 1996; Macdonald, 1998; Holfort and Siedler, 2001; Sloyan and Rintoul, 2001a and b; Zhang et al., 2002; Vanicek and Siedler, 2002). Among the order of 300 OM

20 calculations performed, the analysis based on a the assumptions of a correlation length of $4^{\mathrm{o}}$ and a climatological error of $3 \mathrm{~cm} \mathrm{~s}^{-1}$ provide the best match between our results and those reported in the literature. This set of parameters is used hereinafter (Figure 3, step 9). However, large errors associated with our meridional transport estimates, render our results insignificantly different from estimates given in the literature, which is why we refrain from a detailed presentation. 


\section{Results}

\subsection{The large scale circulation}

Figure 6 shows average velocity, together with 0.63 probability error ellipses. Blue

5 arrows represent flow with a westward zonal component, whereas red arrows indicate flow with an eastward zonal component. Isobaths of 1000 and 3000 meters are displayed. The Subtropical Gyre stands out clearly, with the eastward South Atlantic Current centred around $40^{\circ} \mathrm{S}$ and the westward Subtropical Gyre's northern branch just north of $30^{\circ} \mathrm{S}$. The South Atlantic Current flows at a mean speed of $9.6 \pm 7.8 \mathrm{~cm} \mathrm{~s}^{-1}$. The northern branch of the

10 Subtropical Gyre is located between $22^{\circ} \mathrm{S}$ and $32^{\circ} \mathrm{S}$ and flows westward with a mean speed of $4.7 \pm 3.3 \mathrm{~cm} \mathrm{~s}^{-1}$. The Brazil Current has a mean speed of $11.6 \pm 7.4 \mathrm{~cm} \mathrm{~s}^{-1}$ and flows, south of $30^{\circ} \mathrm{S}$, parallel to the South American coast. The Agulhas Current shows a speed of $25.3 \pm 14.2$ $\mathrm{cm} \mathrm{s}^{-1}$ and the Agulhas Return Current of $22.9 \pm 13.2 \mathrm{~cm} \mathrm{~s}^{-1}$. Currents in the tropical region are quasi zonal and of approximately $3.5 \pm 2.2 \mathrm{~cm} \mathrm{~s}^{-1}$ speed. The mean speeds given and their root mean square errors (as well as those discussed below) were calculated from original float velocities (as calculated from individual displacement-vectors) in the corresponding geographical region. The respective region was chosen visually, based on the objectively estimated velocity map.

Figure 7 displays the results of the objective mapping. We mapped all graticule points

20 within a (averaging) grid cell containing data, or being surrounded by at least four cells with data. The objectively mapped velocity field depicts the Subtropical Gyre comprising the region from $23^{\circ} \pm 1^{\circ} \mathrm{S}$ to $46^{\circ} \pm 1^{\circ} \mathrm{S}$ (the South Atlantic Current meanders between $33^{\circ} \mathrm{S}$ to $46^{\circ} \mathrm{S}$ ). The central part of the gyre (approximately along $36^{\circ} \mathrm{S}$, see section "Transports" below) corresponds to the AAIW layer's region of greatest depth, where the core's isoneutral layer $\left(\gamma^{\mathrm{n}}=27.40\right)$ reaches deeper than 900 dbar. Several local recirculation cells (centred at 
$35^{\circ} \mathrm{S} 41^{\circ} \mathrm{W}, 35^{\circ} \mathrm{S} 29^{\circ} \mathrm{W}$ and $33^{\circ} \mathrm{S} 10^{\circ} \mathrm{W}$ ), might provide short circuits for the "eastern" closure of the Subtropical Gyre. Such a central $\left(35^{\circ} \mathrm{S} 29^{\circ} \mathrm{W}\right)$ recirculation pattern is also present in the geostrophic velocity field calculated by Defant (1941). Just north of the Subtropical Gyre, an eastward current located near $20^{\circ} \mathrm{S}$ (between $10^{\circ} \mathrm{W}$ and $0^{\circ} \mathrm{W}$ ) is present, with a speed of $4.0 \pm$ $5 \quad 2.4 \mathrm{~cm} \mathrm{~s}^{-1}$ (c.f. Richardson and Garzoli (2003)). Most noticeable is the intensification of the Subtropical Gyre along the western boundary, while the eastern closure appears sluggish and to spread out over several branches.

These differences stand out even more clearly in the stream function (Figure 8). Negative streamlines embracing the Subtropical Gyre are depicted in blue while positive 10 contour lines are red. Streamlines are closed and compressed in the Brazil Current region, while the stream function features a broad col in the Cape Basin, with no contour line connecting the Agulhas Current to the nascent Benguela Current. This observation supports the notion of the Cape Basin as a region of turbulent inter-ocean exchange (i.e. the Cape Cauldron, Boebel et al., 2003). There, eddy fluxes dominate both the closure of the

15 Subtropical Gyre as well as the spicing up of fresh Atlantic AAIW with salty Indian Ocean AAIW (Lutjeharms, 1996). Contrastingly, the innermost streamlines of the Subtropical Gyre are closed in the western part of the Cape Basin, near the Walvis Ridge, and hence provide a direct advective route for AAIW to recirculate.

A possible Tropical Gyre is suggested by quasi-closed streamlines farther north 20 (reaching diagonally across the Atlantic). The gyre seems to be divided into a western and eastern sub-cell. While sparse data at these latitudes on the eastern side of the basin do not permit reliable conclusions, the observation does not contradict the concept of three meridionally staggered sub-cells as proposed by Suga and Talley (1995).

Objectively mapped speeds, when compared to those from space-time averages, are 25 underestimated due to the assumption of zero velocity for data gaps inherent to the OM (Emery and Thomson, 1997). 


\subsection{Transports}

Transports were estimated directly from the mapped velocity field, using the variable thickness of the isoneutral layer (see Analysis Section). Figure 9 depicts the mean zonal transport per degree latitude. For the southern branch of the Subtropical Gyre (i.e. the South

5 Atlantic Current) the cumulative transport amounts to approximately $8.5 \mathrm{~Sv}$ (eastward) \pm 3.5 $\mathrm{Sv}$ whereas for the northern branch is $9.3 \mathrm{~Sv}$ (westward) $\pm 3.4 \mathrm{~Sv}$. These values suggest surprisingly well balanced northern and southern branches of the Subtropical Gyre. Errors equal one half the difference between the maximum and minimum transports as given by the shaded region (when calculating errors by the Gaussian law of error propagation, estimates of $\pm 1.1 \mathrm{~Sv} \pm 0.9 \mathrm{~Sv}$ result, respectively).

The core of the South Atlantic Current, as identified by the maximum mean zonal transport, is located at $44^{\circ} \mathrm{S}$. At around $29^{\circ} \mathrm{S}$, the mean zonal transport is a minimum, unveiling the core of the northern branch of the Subtropical Gyre. These values are in good agreement with the observations from Boebel et al. (1999a). As already discussed with our results from the OM, the Subtropical Gyre seems to be centred at about $36^{\circ} \mathrm{S}$, the latitude where the mean zonal transport changes sign. This is in contrast with the $30^{\circ} \mathrm{S}$ from Reid, 1996 and Boebel, 1997 and in good agreement with results from Reid, 1989 (34 S), Schmid, 1998 and Schmid et al, $2000\left(35^{\circ} \mathrm{S}\right)$ as well as Boebel et al., 1999c $\left(35^{\circ} \mathrm{S}\right)$. Nevertheless, it is worth noting the inappropriateness of defining a unique latitude to the centre of the Subtropical Gyre. As visible in Figure 7 and Figure 10 the orientation of the axis is not strictly zonal (as also noticed by Boebel, et al, 1999c), but tilted slightly contra sole.

\section{Discussion}

The general structure of a basin wide Subtropical Gyre, as emerging in Figure 6, with 25 a probably quiescent flow regime to the north (the tropical region), has been developed in previous hydrographic and tracer studies (Rose, 1999; Schlosser et al., 2000). Here, however, 
Lagrangian velocity measurements reveal directly and for the first time the flow structure of the mid-depth Subtropical Gyre across the entire South Atlantic.

A direct comparison of our transport estimates with literature values is complicated by the diversity of measurement and analysis methods used: Lagrangian and Eulerian measurements, inverse models and geostrophy. Additionally, the definition of the AAIW layer (i.e. its vertical boundaries) varies as well. For these reasons, a general agreement of the transports calculated here with those found in the literature would be surprising.

Comparing the meridional transport results (not shown) of the isoneutral layer with those from the isobaric layer, shows virtually identical results between $17^{\circ} \mathrm{S}$ and $40^{\circ} \mathrm{S}$. On the other hand, the transport calculations for the expanded isoneutral layer differ significantly throughout the entire domain. Judging that this later data set comprises significant amounts of water masses adjacent to AAIW, we discarded this data set altogether.

Figure 10 shows the results of the objective mapping for the isobaric layer. The main differences between these results and those obtained for the isoneutral layer (Figure 7) are a)

15 the weaker eastward current just north of the Subtropical Gyre (near $20^{\circ} \mathrm{S}$ and east of the MidAtlantic Ridge), b) currents north of $10^{\circ} \mathrm{S}$ featuring more structure and are mainly zonal, c) the presence of the anticyclonic Zapiola Eddy near $45^{\circ} \mathrm{S} 45^{\circ} \mathrm{W}$, and d) the emergence of parts of the Malvinas/Falkland current between 40 and $45^{\circ} \mathrm{S}$. Estimates of the mean zonal transports (Figure 9) echo these findings: at around $44^{\circ} \mathrm{S}$ the eastward mean zonal transport is a maximum for the isoneutral layer, while within the isobaric layer the maximum transport occurs farther south $\left(47^{\circ} \mathrm{S}\right)$.

Differences between results for the isoneutral layer and results obtained for the isobaric and expanded isoneutral layers (to a lesser degree) are probably due to the inclusion of flows adjacent to the AAIW layer proper. With the AAIW layer outcropping at southern

25 latitudes, for example, the selection of float data within the isobaric layer yields currents from layers beneath the AAIW. As defined by isoneutral surfaces, AAIW is located shallower than 
$400 \mathrm{~m}$ south of $45^{\circ} \mathrm{S}$ and since the floats are drifting deeper than $500 \mathrm{~m}$ throughout, no float data is available within the AAIW isoneutral layer in this region. By contrast many float data are available for the isobaric layer in the same zone. Hence the Malvinas/Falkland Current is partially visible on the objective map depicting flow in the isobaric layer (Figure 10) while it

5 is absent from maps of the isoneutral layer surfaces (Figure 7).

\section{Summary}

This study assembled a float data set of 451 float years, collected over a period of two decades and covering the entire subtropical South Atlantic. The data set comprises data from historical projects as well as data from recent pop-up and acoustically tracked floats. From this data set, three layer-subsets were selected according to the float's depth data lying within the respective vertical regime: isobaric surfaces (650 to $1050 \mathrm{dbar})$, isoneutral surfaces $\left(\gamma^{\mathrm{n}}=\right.$ 27.40 to $\left.\gamma^{\mathrm{n}}=27.55\right)$ and isoneutral surfaces with an expanded layer thickness (50 $\mathrm{m}$ up and 50 down from the aforementioned isoneutral surfaces, respectively).

Space-time averages were formed within grid cells of different size and shapes, following isolines of bathymetry, $f / H$ and $f / h$ to different degrees. The quality of each grid was determined calculating the alignment of the cell shaping field with the resulting mean velocities. We concluded that the grids shaped according to $f / h$ yielded the best results. Within this group, a grid of initial dimensions $3^{\circ}$ latitude $\times 4^{\circ}$ longitude yielded the overall best alignment. It was therefore used to compute space-time averages, error ellipses, as well as meridional and zonal transports.

Subsequently, we objectively mapped these space-time averages using multiple sets of the 'subjective' parameters of the objective analysis, i.e. correlation length and climatological variability. For the ensuing $O(300)$ objective maps we calculated zonal and meridional transports, using the thickness of the AAIW as defined by the isoneutral surfaces. Differences (rms) between meridional transport estimates and literature estimates were calculated. 
Minimum rms differences were yielded when choosing a correlation length of $4^{\circ}$ and a climatological variability of $3 \mathrm{~cm} \mathrm{~s}^{-1}$.

These resulting flow fields reveal a Subtropical Gyre of 9.3 Sv $\pm 3.4 \mathrm{~Sv}$ (mean speed of $\left.4.7 \pm 3.3 \mathrm{~cm} \mathrm{~s}^{-1}\right)$ in the northern branch and $8.5 \mathrm{~Sv} \pm 3.5 \mathrm{~Sv}\left(9.6 \pm 7.8 \mathrm{~cm} \mathrm{~s}^{-1}\right)$ in the South

5 Atlantic Current, within the AAIW layer (confined by the $\gamma^{\mathrm{n}}=27.25$ and $\gamma^{\mathrm{n}}=27.55$ isoneutral surfaces). The gyre's mean latitude is centred near $36^{\circ} \mathrm{S}$, with the gyre reaching from $23^{\circ} \pm 1^{\circ} \mathrm{S}$ to $46^{\circ} \pm 1^{\circ} \mathrm{S}$. Evidence of the existence of a Tropical Gyre divided in two sub-cells is visible on the stream function, where the western intensification stands out clearly.

The main difference between results obtained for the two (isobaric and isoneutral)

10 layers is the absence of the Malvinas/Falkland Current and the Zapiola Eddy from the maps derived for the isoneutral layer. This obviously is due to the outcropping of the AAIW layer at high latitudes. The comparison of results for the isobaric and isoneutral layers suggests further that the isobaric layer provides adequate representation of the AAIW flow only between $17^{\circ} \mathrm{S}$ and $40^{\circ} \mathrm{S}$. Here the two fields are comparable, whereas south and north hereof 15 the results differ markedly.

\section{Acknowledgements}

We would like to thank all the crews, officers, research assistants and researchers contributing to the collection, processing and archiving of float data. In particular, we would like to thank

20 Claudia Schmid for giving us the first data set from AOML/Argo, with which this work started in 2002, as well as Igor Belkin and Reiner Schlitzer (the latter, for his extensive advice related to objective mapping). This work is supported through NSF-Grant no. OCE-0095647 and through the Alfred Wegener Institute for Polar and Marine Research. Olaf Boebel would like to thank Walter Zenk for providing the opportunity to start a career in oceanography and

25 for many years of thoughtful mentoring. The comments of two anonymous reviewers, as well as of the guest editor Gerold Siedler, have contributed significantly to the manuscript. 


\section{Appendix}

Antarctic Intermediate Water was first identified in the South Atlantic, with its discovery commonly attributed to either Georg Wüst (who examined data collected during the 1925-1927 RV Meteor expedition) or George Deacon (summarizing information from several expeditions of the R.R.S. Discovery II (Mills, 2004)). Such abridgement however, provides only an incomplete view of the events that led to the recognition of AAIW. While both, Deacon and Wüst (probably independently) developed the first lasting theory on the AAIW's origins, they did not identify the water mass for the first time. The vertical salinity minimum was in fact first measured during the 1872-1876 Challenger expedition (Buchanan, 1877; according to Talley, 1996). Later measurements during the second German expedition to Antarctica (1911-1912), directed by Wilhelm Filchner onboard the "Deutschland", detected the salinity minimum as well. Analysing these data, Brennecke (1921) describes the motion at the salinity minimum layer as a "sub-Antarctic deep current" and "gives its origin as the surface drift out of the Weddell Sea" (cited from Deacon, 1933, page 222). Only thereafter, Merz and Wüst (1922) published a complete meridional section of salinity, from which it was possible to identify the extent of the salinity minimum (Talley, 1996). Later, Erich von Drygalski, based on data from the first German expedition to Antarctica (1901-1903) aboard "Gauss", describes the water mass related to the salinity minimum as being of Antarctic origins (von Drygalski, 1927, according to Deacon, 1933). To appropriately honour these early discoveries, we chose to include the rarely quoted works of Buchanan (1877) and Brennecke (1921) (as he probably was the first researcher to provide a theory about AAIW's origins), when referring to the discovery of AAIW in the introduction of this manuscript. 


\section{References}

Barlow, R. J., 1989. Statistics. A guide to the use of statistical methods in the physical sciences. John Wiley and Sons. 204 pp.

Barnier, B., Marchesiello, P., Miranda, A. P. d., 1996. The impact of seasonal forcing on the variability of the meridional heat flux at $30^{\circ} \mathrm{S}$ using a sigma-coordinate primitive equation model. International WOCE Newsletter 24, 16-23.

10 Boebel, O., Schmid, C., Zenk, W., 1997. Flow and recirculation of Antarctic Intermediate Water across the Rio Grande Rise. Journal of Geophysical Research C (Oceans) 102 (C9), 20,967-20,986.

Boebel, O., Davis, R. E., Ollitrault, M., Peterson, R. G., Richardson, P. L., Schmid, C., Zenk, 15 W., 1999a. The intermediate depth circulation of the western South Atlantic. Geophysical Research Letters 26 (21), 3329-3332.

Boebel, O., Schmid, C., Podestá, G., Zenk, W., 1999b. Intermediate water at the BrazilMalvinas Confluence Zone: a Lagrangian view. Journal of Geophysical Research 104 (C9), 21063-21082.

Boebel, O., Schmid, C., Zenk, W., 1999c. Kinematic elements of Antarctic Intermediate Water in the western South Atlantic. Deep-Sea Research II 46, 355-392.

Boebel, O., Lutjeharms, J., Schmid, C., Zenk, W., Rossby, T., Barron, C., 2003. The Cape Cauldron: a regime of turbulent interocean exchange. Deep-Sea Research 50 (1), 57-86.

Brennecke, W., 1921. Die ozeanographischen Arbeiten der deutschen Antarktischen Expedition, 1911-1912. Archiv des Deutschen Seewarte 39 (1).

Buchanan, J. Y., 1877. On the distribution of salt in the ocean, as indicated by the specific gravity of its waters. Journal of the Royal Geographical Society 47, 72-86. 
Davis, R. E., Webb, D. C., Regier, L. A., Dufour, J., 1992. The Autonomous Lagrangian Circulation Explorer. Journal of Atmospheric and Oceanic Technology 9, 264 - 285.

Davis, R. E., Killworth, P. D., Blundell, J. R., 1996. Comparison of Autonomous Lagrangian 5 Circulation Explorer and Fine Resolution Antarctic Model results in the South Atlantic. Journal of Geophysical Research 101 (C1), 855 - 884.

Davis, R. E., 1998. Preliminary results from directly measuring mid-depth circulation in the tropical and south Pacific. Journal of Geophysical Research 103 (C11), 24619-24639.

10

Deacon, G. R. E., 1933. A general account of the hydrology of the South Atlantic Ocean. Discovery Reports 7, 171 - 238.

Defant, A., 1941. Quantitative Untersuchungen zur Statik und Dynamik des Atlantischen

15 Ozeans. Wissenschaftliche Ergebnisse der Deutschen Atlantischen Expedition auf dem Forschungs und Vermessungsschiff METEOR 1925-27, Walter de Gruyter und Co. 6, pp. 191-260.

Emery, W. J., Thomson, R. E., 1997. Data analysis methods in physical oceanography. 20 Oxford. Elsevier. 634 pp.

Fu, L.-L., 1981. The general circulation and meridional heat transport of the subtropical South Atlantic determined by inverse methods. Journal of Physical Oceanography 11, 1171-1193. 25

Gille, S. T., 2003. Float observations of the Southern Ocean, Part1: estimating mean fields, bottom velocities and topographic steering. Journal of Physical Oceanography 33, 1167-1181.

Gordon, A. L., Bosley, K. T., 1991. Cyclonic gyre in the tropical South Atlantic. Deep-Sea 30 Research Part A 38 (Supplement 1A), 323-343.

Gould, J., 2005. Float history. Deep-Sea Research II. This volume. 
Hiller, W., Käse, R. H., 1983. Objective analysis of hydrographic data sets from mesoscale surveys. Berichte aus dem Institut für Meereskunde an der Christian-Albrechts-Universität Kiel 116. 78 pp.

5 Holfort, J., 1994. Großräumige Zirkulation und meridionale Transporte im Südatlantik,. Ph.D. Thesis. Abteilung Meeresphysik. Institut für Meereskunde. Kiel. 96 pp.

Holfort, J., Siedler, G., 2001. The meridional oceanic transports of heat and nutrients in the South Atlantic. Journal of Physical Oceanography 31 (1), 5-29.

10

Jackett, D. R., McDougall, T. J., 1997. A neutral density variable for the world's oceans. Journal of Physical Oceanography 27 (2), 237-263.

Jochum, M., Malanotte-Rizzoli, P., 2003. The flow of AAIW along the equator.

Interhemispheric Water Exchanges in the Atlantic Ocean, Elsevier Series. pp. 193-212.

LaCasce, 2000. Floats and f/H. Journal of Marine Research 58, 61-95.

Lutjeharms, J. R. E., 1996. The exchange of water between the South Indian and South

Atlantic Oceans. The South Atlantic: present and past circulation. G. Wefer, W. H. Berger, G.

Siedler and D. Webb. Berlin-Heidelberg, Springer-Verlag. pp. 122 - 162.

Macdonald, A. M., 1993. Property fluxes at $30^{\circ} \mathrm{S}$ and their implications for the Pacific-Indian troughflow and the global heat budget. Journal of Geophysical Research 98, 6851-6868.

Macdonald, A. M., 1998. The global ocean circulation: a hydrographic estimate and regional analysis. Progress in Oceanography 41, 281-382.

Matano, R., Philander, G., 1993. Heat and mass balances of the South Atlantic ocean calculated from a numerical model. Journal of Geophysical Research 98 (C1), 977-984.

McDougall, T. J., 1987. Neutral surfaces. Journal of Physical Oceanography 17 (11), 19501964. 
Merz, A., Wüst, G., 1922. Die atlantische Vertikalzirkulation. Zeitschrift der Gesellschaft für Erdkunde zu Berlin 1 (Vorträge und Abhandlungen), 1-35.

Mills, E. L., 2004. The hydrology of the Southern Ocean, 1885-1937. WWW Page,

5 http://www.soc.soton.ac.uk/Discovery/EMills_Abstract.html.

Molinari, R. L., Voituriez, B., Duncan, P., 1981. Observations in the subthermocline undercurrent of the equatorial South Atlantic Ocean: 1978-1980. Oceanologica Acta 4, 451456.

10

Ollitrault, M., 1994. The TOPOGOLF experiment: lagrangian data. Brest, France. Editions de L'Ifremer. IFREMER - Centre de Brest. 622 pp.

Ollitrault, M., Cortes, N., Loaëc, G., Rannou, J.-P., 1994. MARVOR float present results from the SAMBA experiment. OCEANS 94 proceedings III (OCEANS 94 OSATES conference). pp. 17-22.

Ollitrault, M., Auffret, Y., Cortes, N., Hemon, C., Jegou, P., Le Reste, S., Loaec, G., Rannou, J. P., 1995. The SAMBA experiment. Volume 1: SAMBA 1 Lagrangian and CTD data 20 (February 1994-August 1995). IFREMER. Brest. 488 pp.

Ollitrault, M., 1999. MARVOR floats reveal intermediate circulation in the western equatorial and tropical South Atlantic (30S to 5N). WOCE Newsletter 34, 7-10.

25 Reid, J. L., 1989. On the total geostrophic circulation of the South Atlantic Ocean: Flow patterns, tracers and transports. Progress in Oceanography 23, (3), 149-244.

Reid, J. L., 1994. On the total geostrophic circulation of the North Atlantic Ocean: Flow patterns, tracers and transports. Progress in Oceanography 33, 1 - 92.

30

Reid, J. R., 1996. On the circulation of the South Atlantic Ocean. The South Atlantic: Present and past circulation. G. Wefer, W. H. Berger, G. Siedler and D. J. Webb. Berlin Heidelberg, Springer-Verlag. pp. 13 - 44. 
Richardson, P. L., 1992. Velocity and eddy energy of the Gulf Steam system from 700-m SOFAR floats subsampled to simulate Pop-Up floats. Journal of Atmospheric and Oceanic Technology 9, 495-503.

5 Richardson, P. L., Schmitz, W. J., 1993. Deep cross-equatorial flow in the Atlantic measured with SOFAR floats. Journal of Geophysical Research 98, 8371 - 8388.

Richardson, P. L., Garzoli, S. L., 2003. Characteristics of Intermediate Water flow in the Benguela Current as measured with RAFOS floats. Deep-Sea Research II 50 (1), 87-118.

10

Rintoul, S. R., 1991. South Atlantic interbasin exchange. Journal of Geophysical Research 96, 2675-2692.

Roemmich, D., 1983. The balance of geostrophic and Ekman transports in the tropical Atlantic ocean. Journal of Physical Oceanography 13, 1534-1539.

Rose, H., 1999. Untersuchung der Zirkulation und der Erneuerung des Antarktischen Zwischenwassers im Südatlantik aus FCKW-Daten. PhD. Thesis. Universität Bremen, Fachbereich 1. Institut für Umweltphysik.

Rossby, T., Webb, D. C., 1970. Observing abyssal motions by tracking swallow floats in the SOFAR channel. Deep-Sea Research 17, 359-365.

Rossby, H. T., Levine, E. R., Connors, D. N., 1985. The isopycnal Swallow Float - a simple 25 device for tracking water parcels in the ocean. Progress in Oceanography 14, 511-525.

Rossby, H. T., Dorson, D., Fontaine, J., 1986. The RAFOS System. Journal of Atmospheric and Oceanic Technology 3 (4), 672-679.

30 Saunders, P. M., King, B. A., 1995. Bottom currents derived from shipborne ADCP on WOCE cruise A11 in the South Atlantic. Journal of Physical Oceanography 25, 329-347. 
Schlitzer, R., 1996. Mass and heat transports in the South Atlantic derived from historical hydrographic data. The South Atlantic. Present and Past Circulation. G. Wefer, W. H. Berger, G. Siedler and D. J. Webb, Springer. pp. 305-323.

5 Schlosser, P., Bullister, J. L., fine, R., Jenkins, W. J., Key, R., Lupton, J., Roether, W., Smethie, W. M., 2000. Transformation and age of water masses. Ocean circulation and climate. G. Siedler, J. Church and J. Gould, Academic Press. pp. 431-452.

Schmid, C., 1998. Die Zirkulation des Antarktischen Zwischenwassers im Südatlantik. Ph.D. Thesis. Deptartment of Ocean Physics. University of Kiel. Kiel. 104 pp.

Schmid, C., Siedler, G., Zenk, W., 2000. Dynamics of intermediate water circulation in the subtropical South Atlantic. Journal of Physical Oceanography 30 (12), 3191-3211.

15 Schmid, C., Molinari, R. L., Garzoli, S. L., 2001. New observations of the intermediated depth circulation in the tropical Atlantic. Journal of Marine Research 59, 281-312.

Schmid, C., Borulès, B., Gouriou, Y., 2005. Impact of the deep equatorial jets on the zonal transport in the Atlantic. Deep-Sea Research Part II. This volume.

Sloyan, B. M., Rintoul, S. R., 2001. The Southern Ocean limb of the global deep overturning circulation. Journal of Physical Oceanography 31 (1), 143-173.

Sloyan, B. M., Rintoul, S. R., 2001b. Circulation, renewal, and modification of Antarctic 25 Mode and Intermediate Water. Journal of Physical Oceanography 31 (4), 1005-1030.

Smith, W. H. F., Sandwell, D. T., 1997. Global seafloor topography from satellite altimetry and ship depth soundings. Science 277, 1957-1962.

30 Speer, K. G., Holfort, J., Reynaud, T., Siedler, G., 1996. South Atlantic heat transport at $11^{\circ}$ S. The South Atlantic: Present and Past Circulation. G. Wefer, W. Berger, H., G. Siedler and D. J. Webb. Berlin Heidelberg, Springer-Verlag. pp. 105-120. 
Stramma, L., Peterson, R. G., 1989. Geostrophic transport in the Benguela current region. Journal of Physical Oceanography 19, 1440-1448.

5 Stramma, L., Peterson, R. G., 1990. The South Atlantic current. Journal of Physical Oceanography 20 (6), 846-859.

Suga, T., Talley, L. D., 1995. Antarctic Intermediate Water circulation in the tropical and subtropical South Atlantic. Journal of Geophysical Research 100 (C7), 13441-13453.

Talley, L. D., 1996. Antarctic Intermediate Water in the South Atlantic. The South Atlantic: present and past circulation. G. Wefer, W. H. Berger, G. Siedler and D. Webb. BerlinHeidelberg,, Springer-Verlag. pp. 219-238.

15

Tomczak, M., Godfrey, J. S., 1994. Regional oceanography: an introduction. Pergamon. 422 pp.

Vanicek, M., Siedler, G., 2002. Zonal fluxes in the deep water layers of the western South 20 Atlantic ocean. Journal of Physical Oceanography 32 (8), 2205-2235.

Von Drygalski, E. V., 1927. Deutsche Südpolar Expedition, 1901-1903, VII, Ozeanographie.

Wüst, G., 1935. Schichtung und Zirkulation des Atlantischen Ozeans, Die Stratosphäre.

Wissenschaftliche Ergebnisse der Deutschen Atlantischen Expedition auf dem Forschungsund Vermessungsschiff "Meteor" 1925-1927. 6. 180 pp. English translation edited by William J. Emery: "The stratosphere of the Atlantic Ocean. Scientific Results of the German Atlantic Expedition of the Research Vessel 'Meteor' 1925-27". Published by Amerind Publishing Co., 1978.

30

You, Y., 1998. Intermediate water circulation and ventilation of the Indian Ocean derived from water-mass contributions. Journal of Marine Research 56, 1029-1067. 
You, Y., 1999. Dianeutral mixing, transformation and transport of Antarctic Intermediate Water in the South Atlantic Ocean. Deep-Sea Research II 46, 393-435.

You, Y., 2002. Quantitative estimate of Antarctic Intermediate Water contributions from the

5 Drake Passage and the southwest Indian Ocean to the South Atlantic. Journal of Geophysical Research 107 (C4), 6-1 - 6-20.

You, Y., Lutjeharms, J., Boebel, O., de Ruijter, W. P. M., 2003. Quantification of the interocean exchange of intermediate water masses around southern Africa. Deep-Sea 10 Research II 50 (1), 197-228.

Zenk, W., Schmid, C., Boebel, O., 1998. WOCE floats in the South Atlantic. International WOCE Newsletter 30, 39-43.

15 Zhang, D., McPhaden, M. J., Johns, W. E., 2002. Interior ocean pycnocline transports in the Atlantic subtropical cells. Exchanges. Clivar Selected Research Papers 25, 1-4. 


\section{Figure Captions}

Figure 1. Meridional section of AAIW salinity along approximately $25^{\circ} \mathrm{W}$, from South Georgia Island to Iceland. Data collected between 1988 and1989. The two curves overlying the AAIW low salinity core are the 31.7 and $31.9 \sigma_{1}$ isopycnal contours. Modified from Talley (1996, her Figure 1 (a)).

Figure 2. Schematic of AAIW circulation in the South Atlantic (adapted from You (1999)).

Figure 3. Flow chart of float data processing. Data sets are enclosed by ellipses, data processes by rectangles. Consecutive numbers identify each process and are cross-referenced throughout the manuscript.

Figure 4. Final grid as used for computation of space-time averages. Cell shapes are developed starting from a regular grid of $3^{\circ}$ (latitude) $x 4^{\circ}$ (longitude) which are deformed according to $f / h$ using equation 1 with $\mu=6000$.

Figure 5. Number of float-days within isoneutral layer.

Figure 6. Average velocities for grid shown in Figure 4. The corresponding 63\% probability error ellipses are centred on the tip of each velocity arrow.

Figure 7. Objectively mapped velocities from float data within isoneutral layer. Gray arrows indicate eastward and black arrows westward currents. A reference arrow of $5 \mathrm{~cm} \mathrm{~s}^{-1}$ is added.

Figure 8. Stream function calculated from float data within isoneutral layer. Contour values are in units of transport per depth $\left(\mathrm{Sv} \mathrm{km}{ }^{-1}\right)$.

Figure 9. Lagrangian mean zonal transport across the South Atlantic ocean. The continuous thick line (dark shaded area) represents the transport (error estimate) within the isoneutral layer, whereas the dotted line (light shaded area) describes the layer transport within the isobaric layer. Values are in Sv per degree latitude (positive east). The cumulative transports of the South Atlantic Current and of the northern branch of the Subtropical Gyre are indicated. 
Figure 10. Objectively mapped velocities from float data within the isobaric layer ( between 650 and 1050 dbar). Gray arrows indicate eastward and black arrows westward currents. A reference arrow of $5 \mathrm{~cm} \mathrm{~s}^{-1}$ is added. 


\section{Tables}

Table 1. Overview of float data by program. APEX: Autonomous Profiling Explorer; PALACE : Profiling ALACE (Autonomous Lagrangian Circulation Explorer), RAFOS: Ranging and Fixing of Sound; Marvor: Breton word for seahorse.

\begin{tabular}{|c|c|c|c|c|c|c|c|c|c|c|c|c|}
\hline \multirow{2}{*}{$\begin{array}{c}\begin{array}{c}\text { Program } \\
\text { identification }\end{array} \\
\text { AWI }\end{array}$} & \multirow{2}{*}{$\begin{array}{c}\begin{array}{c}\text { Number } \\
\text { of floats }\end{array} \\
38\end{array}$} & \multirow{2}{*}{$\begin{array}{l}\begin{array}{l}\text { Float } \\
\text { type }\end{array} \\
\text { APEX }\end{array}$} & \multicolumn{2}{|c|}{$\begin{array}{c}\text { First } \\
\text { transmission } \\
(\mathrm{m} / \mathrm{y})\end{array}$} & \multicolumn{2}{|c|}{$\begin{array}{l}\text { Last } \\
\text { transmission } \\
(\mathrm{m} / \mathrm{y})\end{array}$} & \multirow{2}{*}{$\begin{array}{c}\begin{array}{c}\text { Number } \\
\text { of float } \\
\text { years }\end{array} \\
27\end{array}$} & \multicolumn{4}{|c|}{$\begin{array}{l}\text { Area in which the } \\
\text { floats drifted } \\
\text { (lat1-lat2, lon1-lon2) }\end{array}$} & \multirow[t]{2}{*}{ References } \\
\hline & & & 3 & 2000 & 3 & 2003 & & -69 & -48 & -6 & 401 & \\
\hline Argo & 60 & Various & 8 & 1997 & 6 & 2003 & 62 & -43 & -4 & -49 & $30 !$ & http://argo.jcommops.org/ \\
\hline WOCE/DBE & 42 & PALACE & 11 & 1994 & 1 & 1999 & 72 & -61 & -25 & -68 & 401 & Davis et al., 1996; Davis 1998 \\
\hline KAPEX & 101 & RAFOS & 3 & 1997 & 9 & 1999 & 94 & -50 & -18 & -31 & 401 & Boebel et al., 2003 \\
\hline WOCE & 71 & RAFOS & 12 & 1992 & 10 & 1996 & 60 & -45 & -4 & -56 & -132 & Zenk et al., 1998 \\
\hline SAMBA & 74 & Marvor & 2 & 1994 & 12 & 2001 & 136 & -46 & -4 & -55 & -4 & Ollitrault, et al. 1995 \\
\hline cumulative & 386 & & 12 & 1992 & 6 & 2003 & 451 & -69 & -4 & -68 & 40 & \\
\hline
\end{tabular}


Table 2. Alignment numbers as calculated for various grid configurations. The first two columns describe the dimensions of the original rectangular cells before deformation (in degrees of latitude and longitude, respectively). The third column indicates the $\mu$ value applied in the deformation process. The next three columns specify alignment numbers corresponding to grids deformed using $\mu$ with one of three governing variables $f / H, f / h$ and bathymetry. Minimum values for each variable and grid size are marked shaded with overall minimum value (within each group of grid sizes) are printed bold.

Alignment Number

Alignment Number

\begin{tabular}{cccccc} 
Lat & Lon & mu & f/H & f/h & Bath \\
\hline 2 & 3 & 0 & 0.9417 & 0.9291 & 0.7922 \\
2 & 3 & 100 & 0,937 & 0,777 & 0,915 \\
2 & 3 & 300 & 0,935 & 0,772 & 0,903 \\
2 & 3 & 500 & 0,913 & 0,776 & 0,907 \\
2 & 3 & 700 & 0,902 & 0,779 & 0,877 \\
2 & 3 & 900 & 0,927 & 0,77 & 0,87 \\
2 & 3 & 1100 & 0,931 & - & 0,858 \\
2 & 3 & 1500 & - & 0,755 & - \\
2 & 3 & 3000 & - & 0,785 & - \\
2 & 3 & 6000 & - & $\mathbf{0 , 7 5 1}$ & - \\
\hline 2 & 4 & 0 & 0.9385 & 0.8535 & $\mathbf{0 . 7 1 6 7}$ \\
2 & 4 & 100 & 0,849 & 0,731 & 0,948 \\
2 & 4 & 300 & 0,863 & 0,735 & 0,907 \\
2 & 4 & 500 & 0,848 & 0,737 & 0,866 \\
2 & 4 & 700 & 0,832 & 0,736 & 0,852 \\
2 & 4 & 900 & 0,856 & 0,729 & 0,873 \\
2 & 4 & 1100 & 0,826 & 0,732 & 0,87 \\
2 & 4 & 1500 & - & 0,742 & - \\
2 & 4 & 3000 & - & 0,742 & - \\
2 & 4 & 6000 & - & - & - \\
\hline 3 & 4 & 0 & 0.9307 & 0.8145 & 0.7072 \\
3 & 4 & 100 & 0,766 & 0,683 & 0,922 \\
3 & 4 & 300 & 0,745 & 0,703 & 0,922 \\
3 & 4 & 500 & 0,764 & 0,702 & 0,944 \\
3 & 4 & 700 & 0,734 & 0,703 & 0,912 \\
3 & 4 & 900 & 0,71 & 0,718 & 0,929 \\
3 & 4 & 1100 & 0,714 & - & 0,908 \\
3 & 4 & 1500 & - & 0,686 & - \\
3 & 4 & 3000 & - & 0,671 & - \\
3 & 4 & 6000 & - & $\mathbf{0 , 6 4 6}$ & - \\
\hline 3 & 6 & 0 & 1.1094 & 0.9191 & 0.7921 \\
3 & 6 & 100 & 0,853 & 0,737 & 1,108 \\
3 & 6 & 300 & 0,906 & 0,754 & 1,116 \\
3 & 6 & 500 & 0,885 & 0,757 & 1,06 \\
3 & 6 & 700 & 0,866 & 0,745 & 1,038
\end{tabular}

\begin{tabular}{cccccc} 
Lat & Lon & $\mathbf{m u}$ & $\mathbf{f} / \mathbf{H}$ & $\mathbf{f} / \mathbf{h}$ & Bath \\
\hline 4 & 5 & 0 & 0.9434 & 0.7989 & 0.6271 \\
4 & 5 & 100 & 0,784 & 0,612 & 0,937 \\
4 & 5 & 300 & 0,696 & 0,61 & 0,849 \\
4 & 5 & 500 & 0,761 & 0,623 & 0,83 \\
4 & 5 & 700 & 0,797 & 0,622 & 0,79 \\
4 & 5 & 900 & 0,814 & 0,632 & 0,871 \\
4 & 5 & 1100 & 0,822 & - & 0,968 \\
4 & 5 & 1500 & - & 0,643 & - \\
4 & 5 & 3000 & - & $\mathbf{0 , 5 8 6}$ & - \\
4 & 5 & 6000 & - & 0,635 & - \\
\hline 4 & 8 & 0 & 0.7560 & 0.6216 & 0.5644 \\
4 & 8 & 100 & 0,649 & $\mathbf{0 , 5 3}$ & 0,828 \\
4 & 8 & 300 & 0,637 & 0,558 & 0,839 \\
4 & 8 & 500 & 0,69 & 0,58 & 0,833 \\
4 & 8 & 700 & 0,627 & 0,585 & 0,756 \\
4 & 8 & 900 & 0,648 & 0,556 & 0,777 \\
4 & 8 & 1100 & 0,706 & - & 0,88 \\
4 & 8 & 1500 & - & 0,612 & - \\
4 & 8 & 3000 & - & 0,622 & - \\
4 & 8 & 6000 & - & 0,666 & - \\
\hline 5 & 5 & 0 & 0.8567 & 0.7462 & 0.7396 \\
5 & 5 & 100 & 0,739 & 0,754 & 0,871 \\
5 & 5 & 300 & $\mathbf{0 , 6 9 7}$ & 0,738 & 0,868 \\
5 & 5 & 500 & 0,712 & 0,733 & 0,828 \\
5 & 5 & 700 & 0,723 & 0,72 & 0,816 \\
5 & 5 & 900 & 0,706 & 0,705 & 0,809 \\
5 & 5 & 1100 & 0,716 & - & 0,789 \\
5 & 5 & 1500 & - & 0,801 & - \\
5 & 5 & 3000 & - & 0,785 & - \\
5 & 5 & 6000 & - & 0,765 & - \\
\hline & & & & &
\end{tabular}




$\begin{array}{cccccc}3 & 6 & 900 & 0,848 & 0,722 & 1,02 \\ 3 & 6 & 1100 & 0,833 & - & 1,013 \\ 3 & 6 & 1500 & - & 0,711 & - \\ 3 & 6 & 3000 & - & 0,58 & - \\ 3 & 6 & 6000 & - & \mathbf{0 , 5 5 1} & -\end{array}$

(Table 2: continued)

\section{Table Captions}

Table 1. Overview of float data by program. APEX: Autonomous Profiling Explorer; PALACE : Profiling ALACE (Autonomous Lagrangian Circulation Explorer), RAFOS: Ranging and Fixing of Sound; Marvor: Breton word for seahorse.

Table 2. Alignment numbers as calculated for various grid configurations. The first two columns describe the dimensions of the original rectangular cells before deformation (in degrees of latitude and longitude, respectively). The third column indicates the $\mu$ value applied in the deformation process. The next three columns specify alignment numbers corresponding to grids deformed using $\mu$ with one of three governing variables $f / H, f / h$ and bathymetry. Minimum values for each variable and grid size are marked shaded with overall minimum value (within each group of grid sizes) are printed bold. 
Figure1

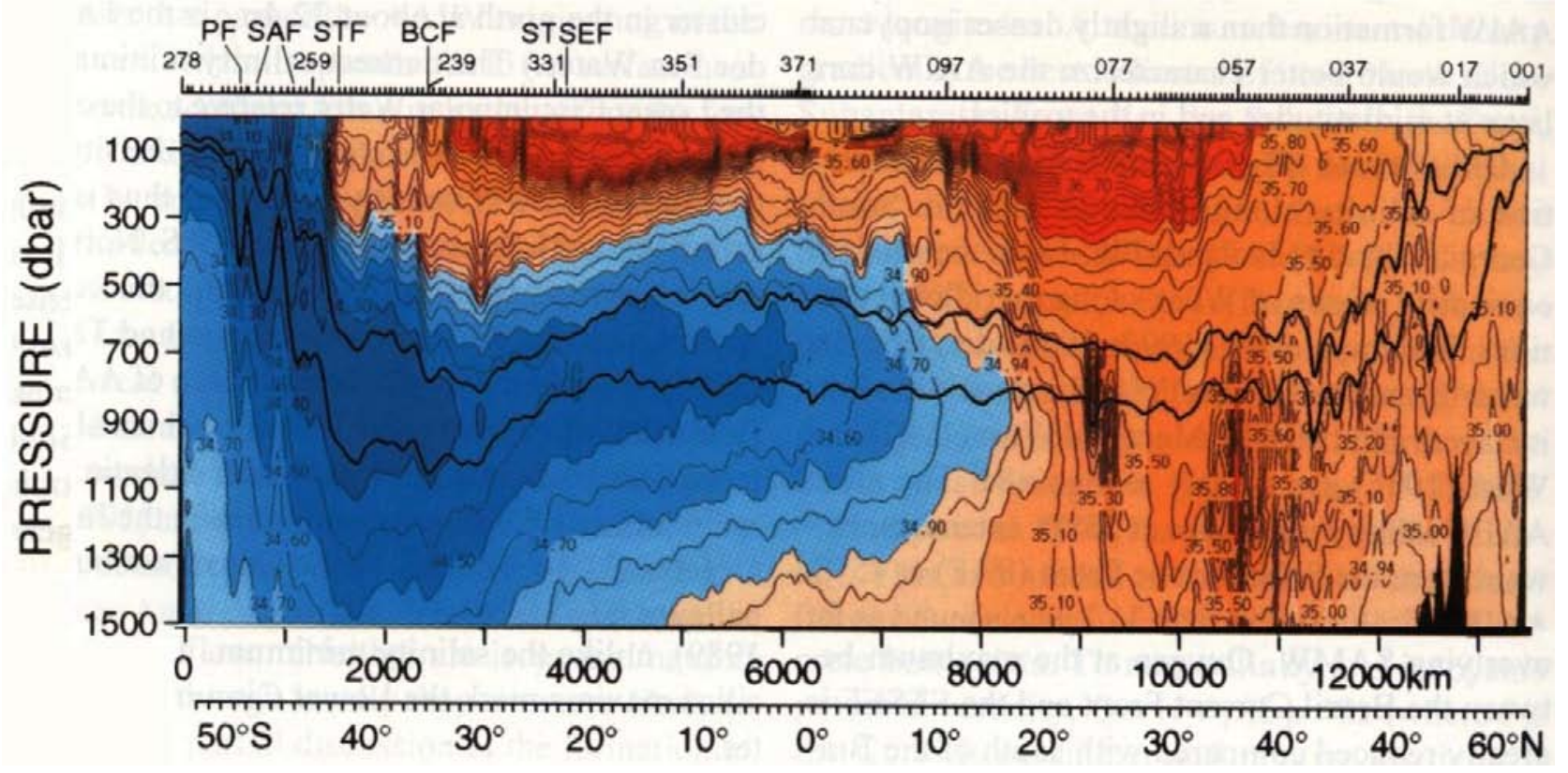


Figure 2

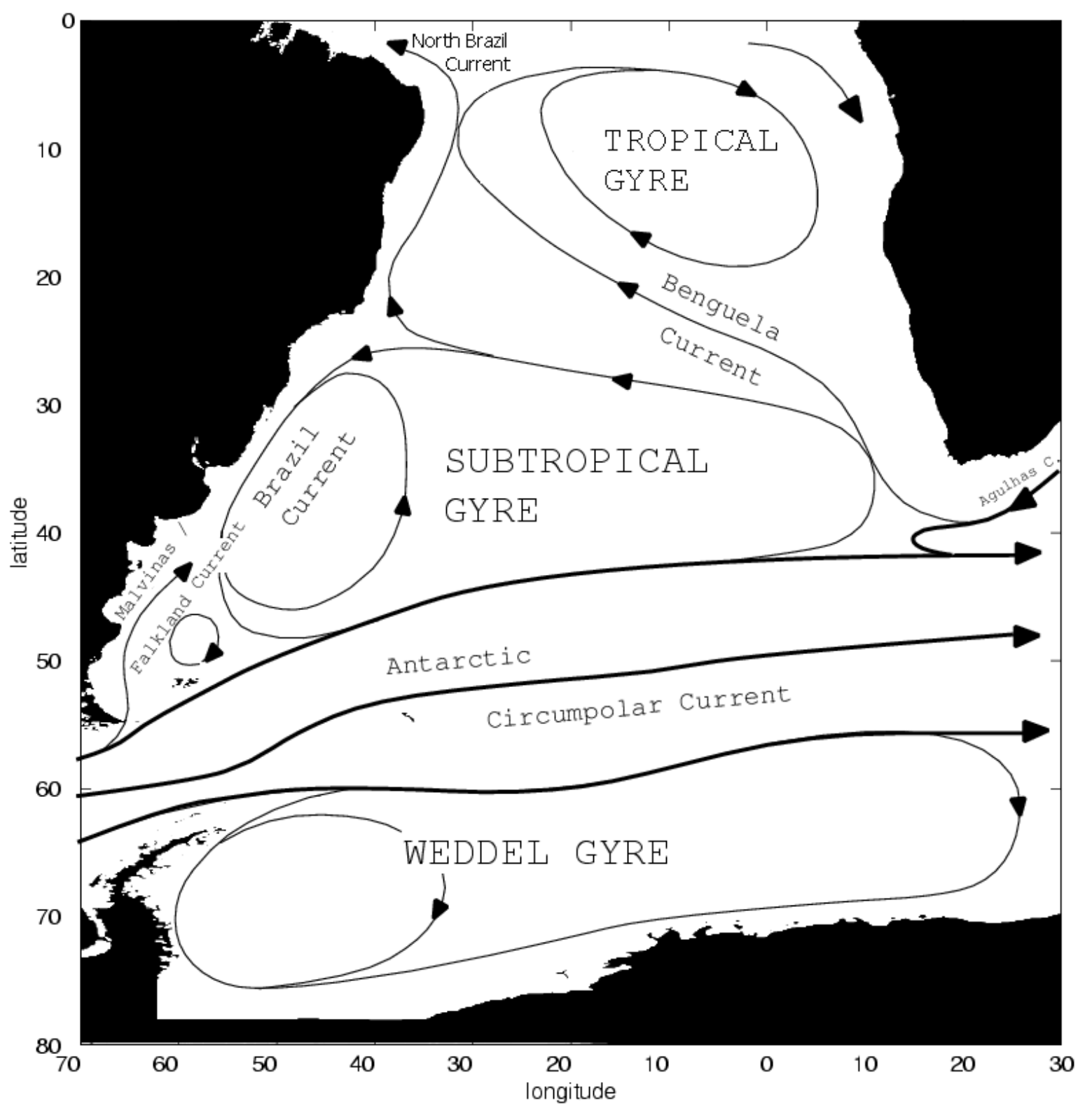


Figure 3

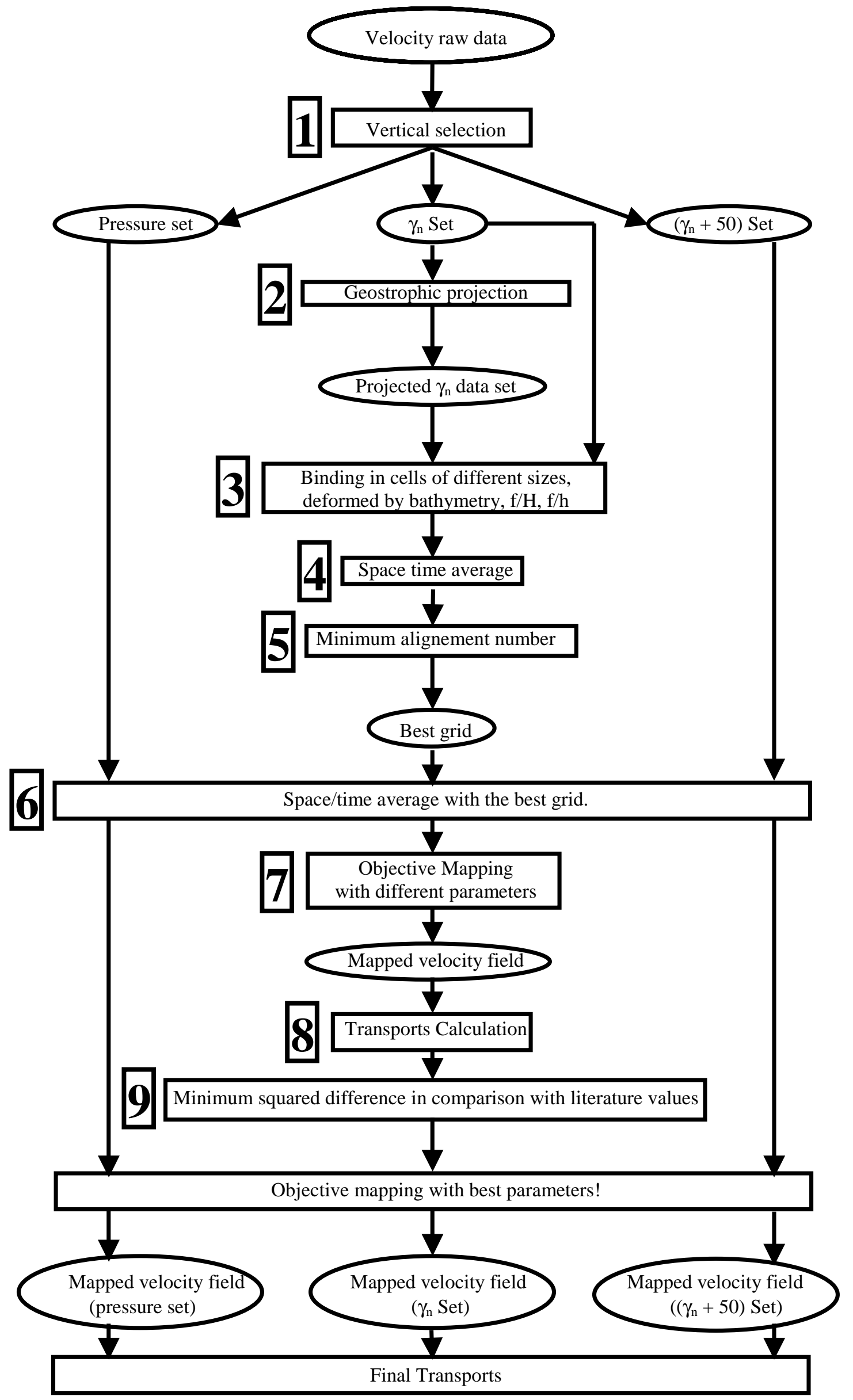


Figure 4

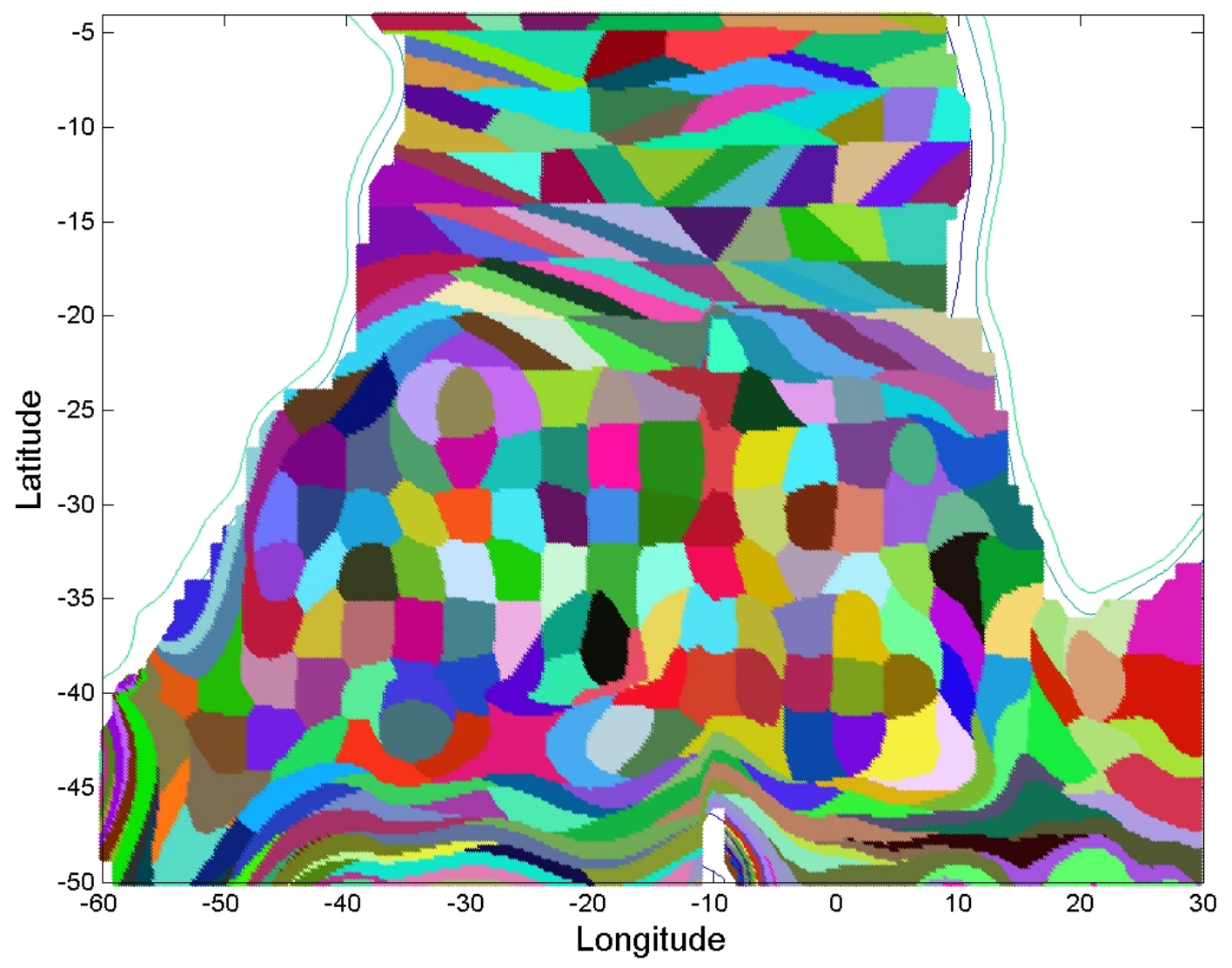


Figure 5

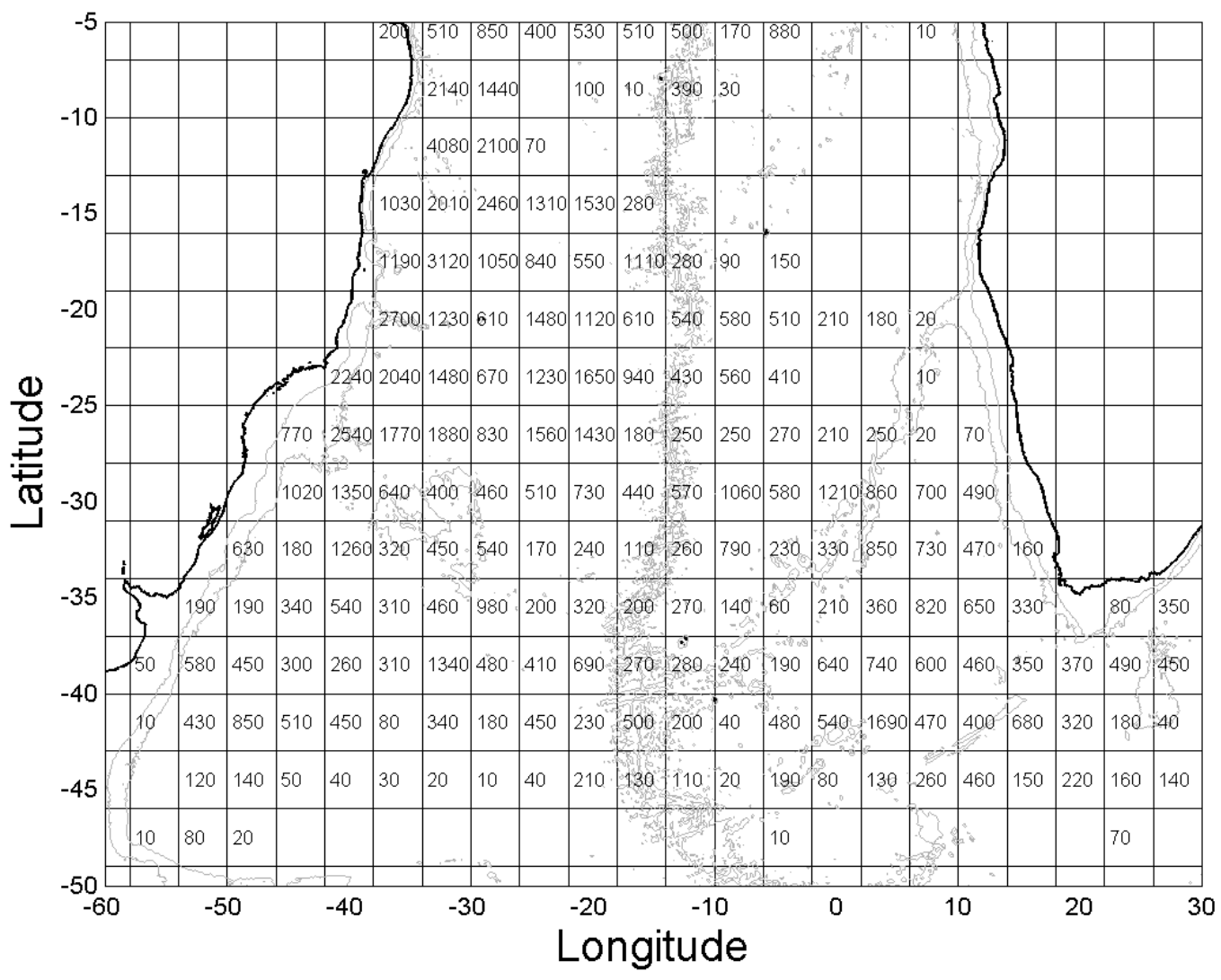


Figure 6

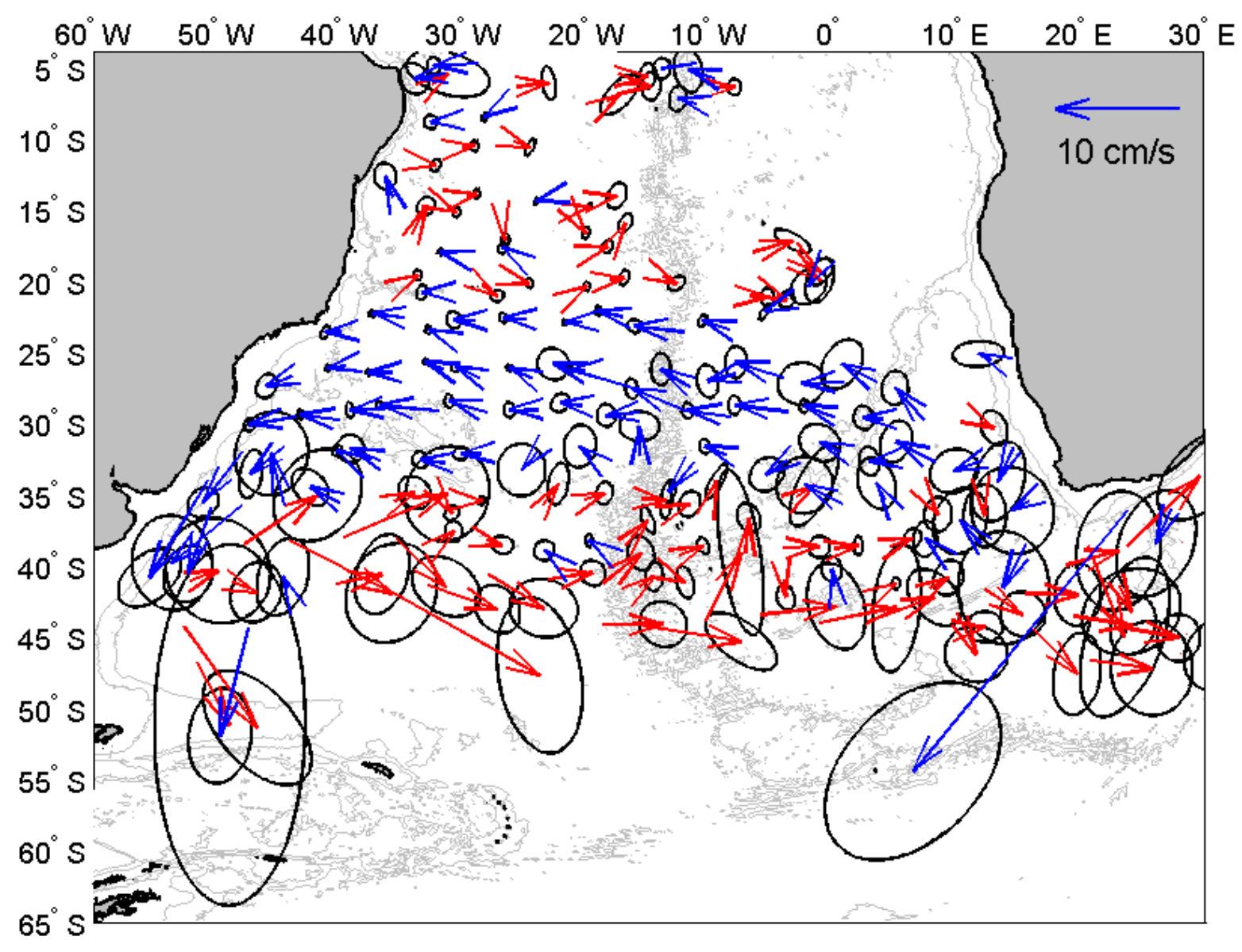


Figure 7

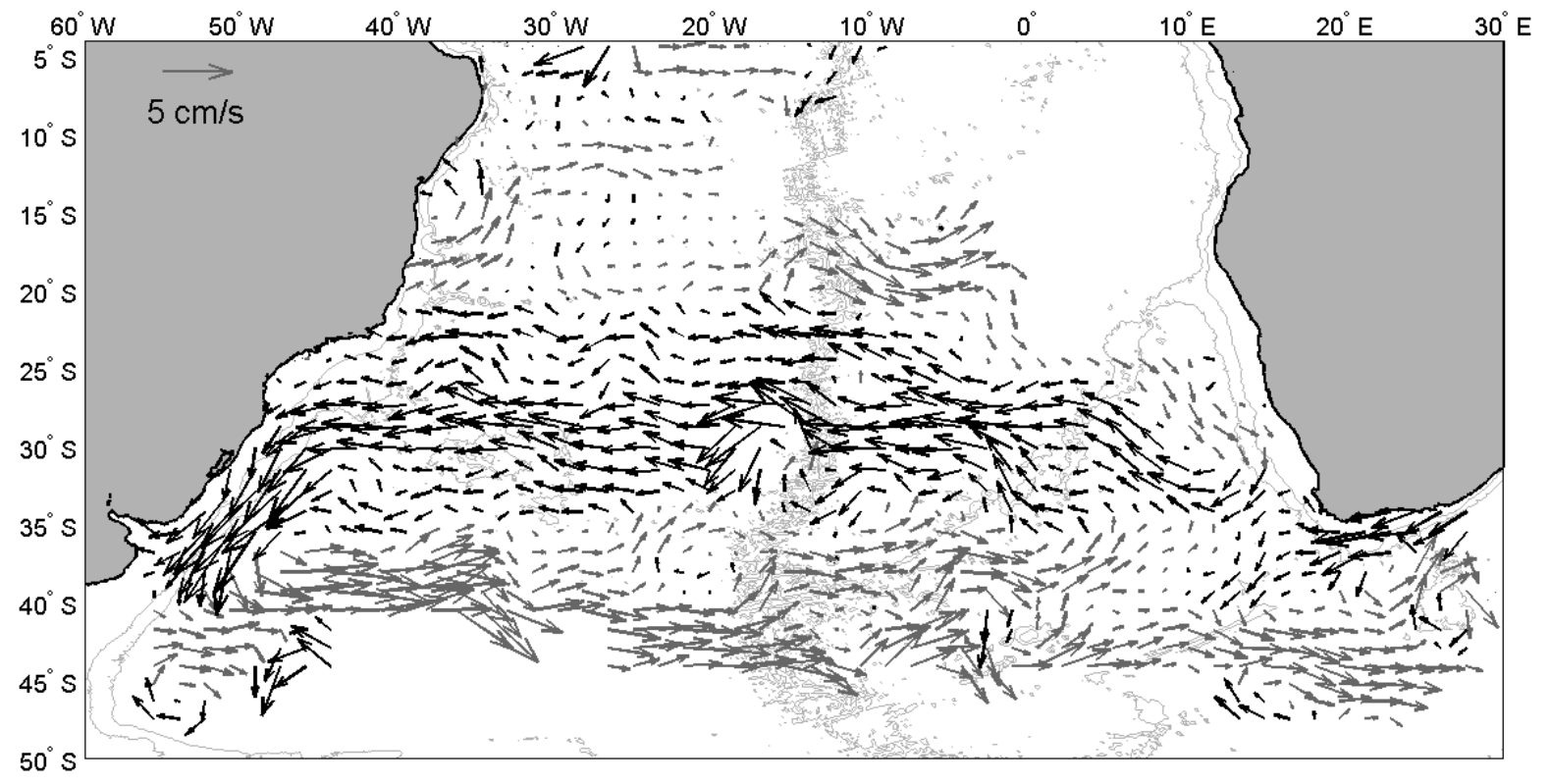


Figure 8

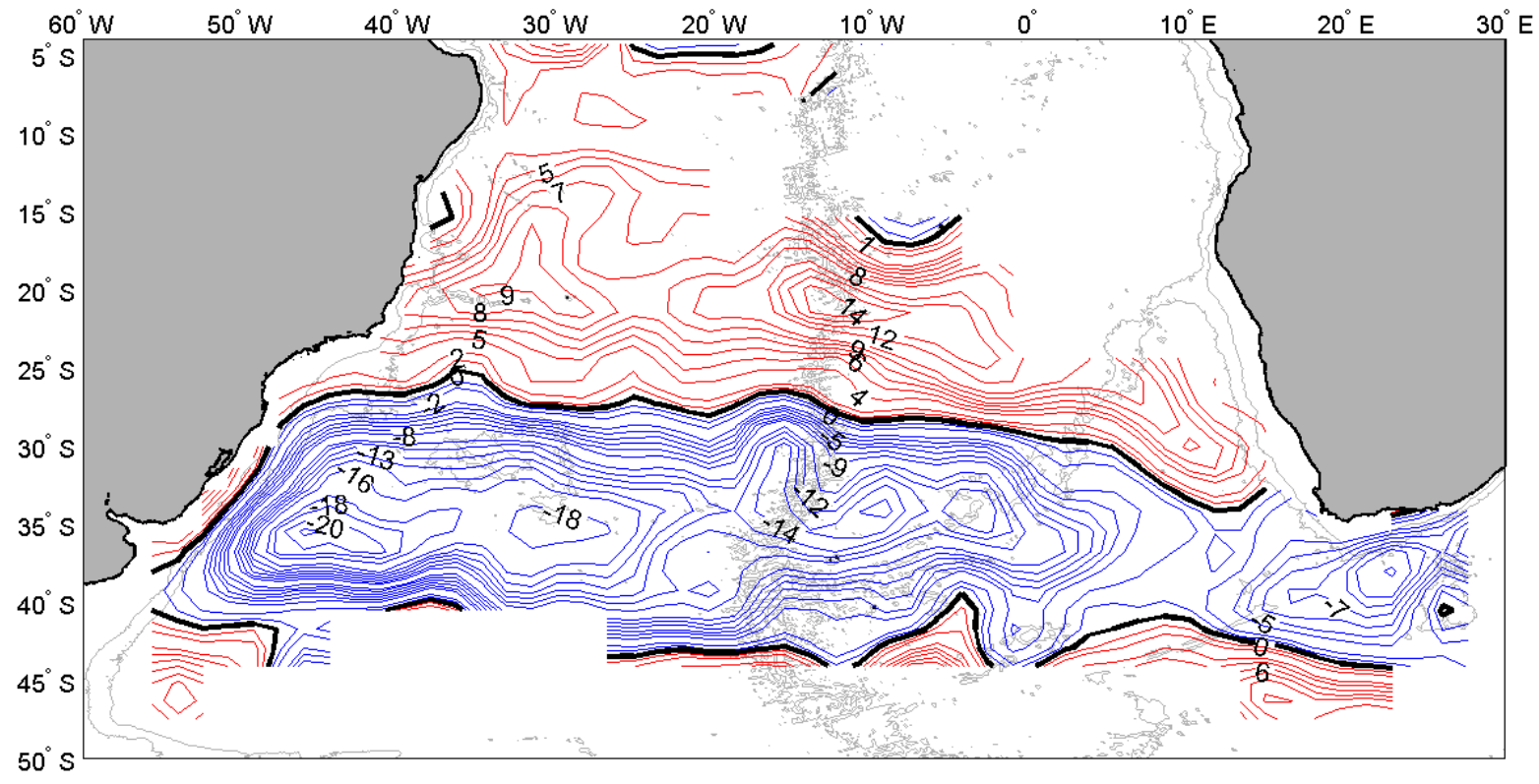


Figure 9

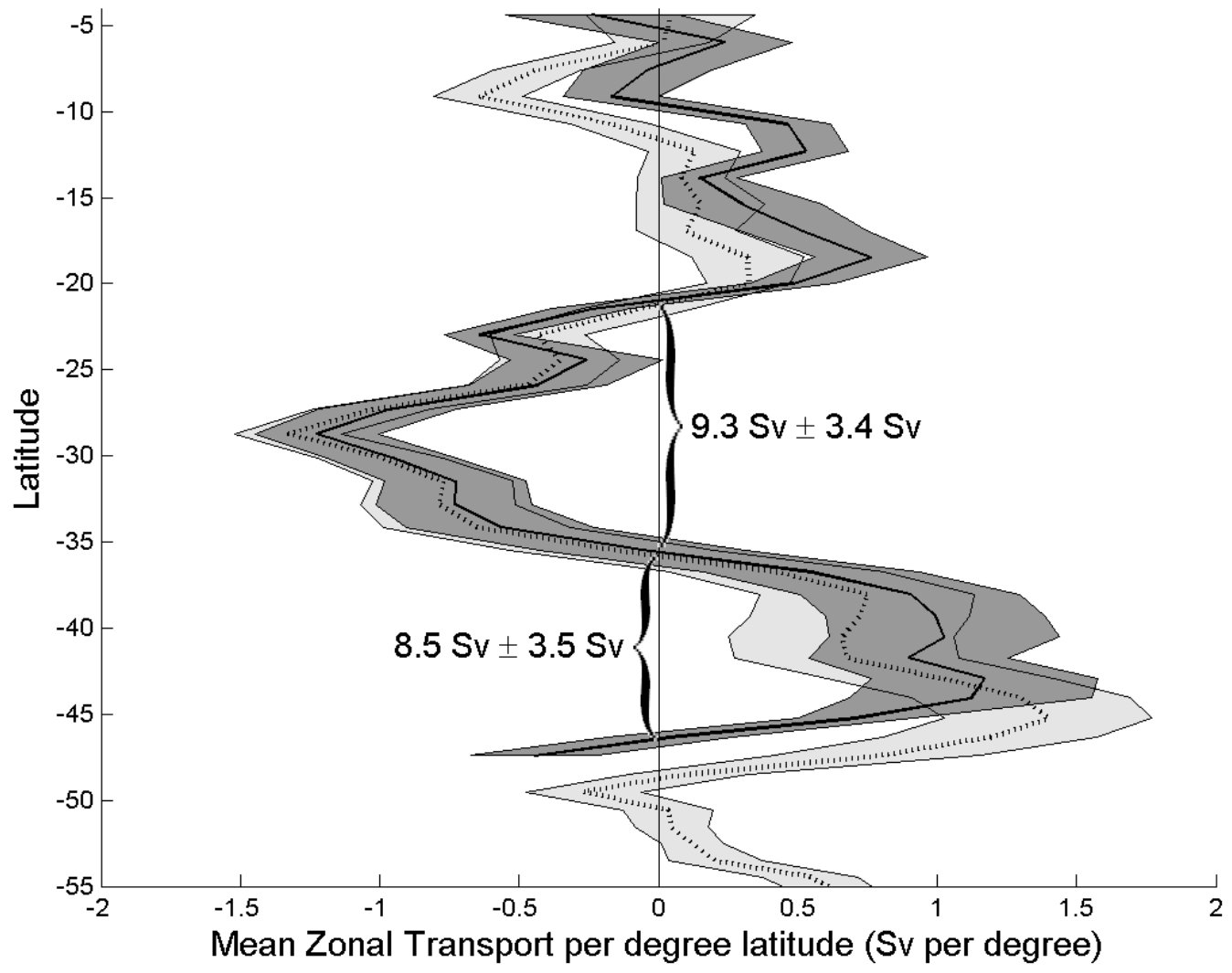


Figure 10

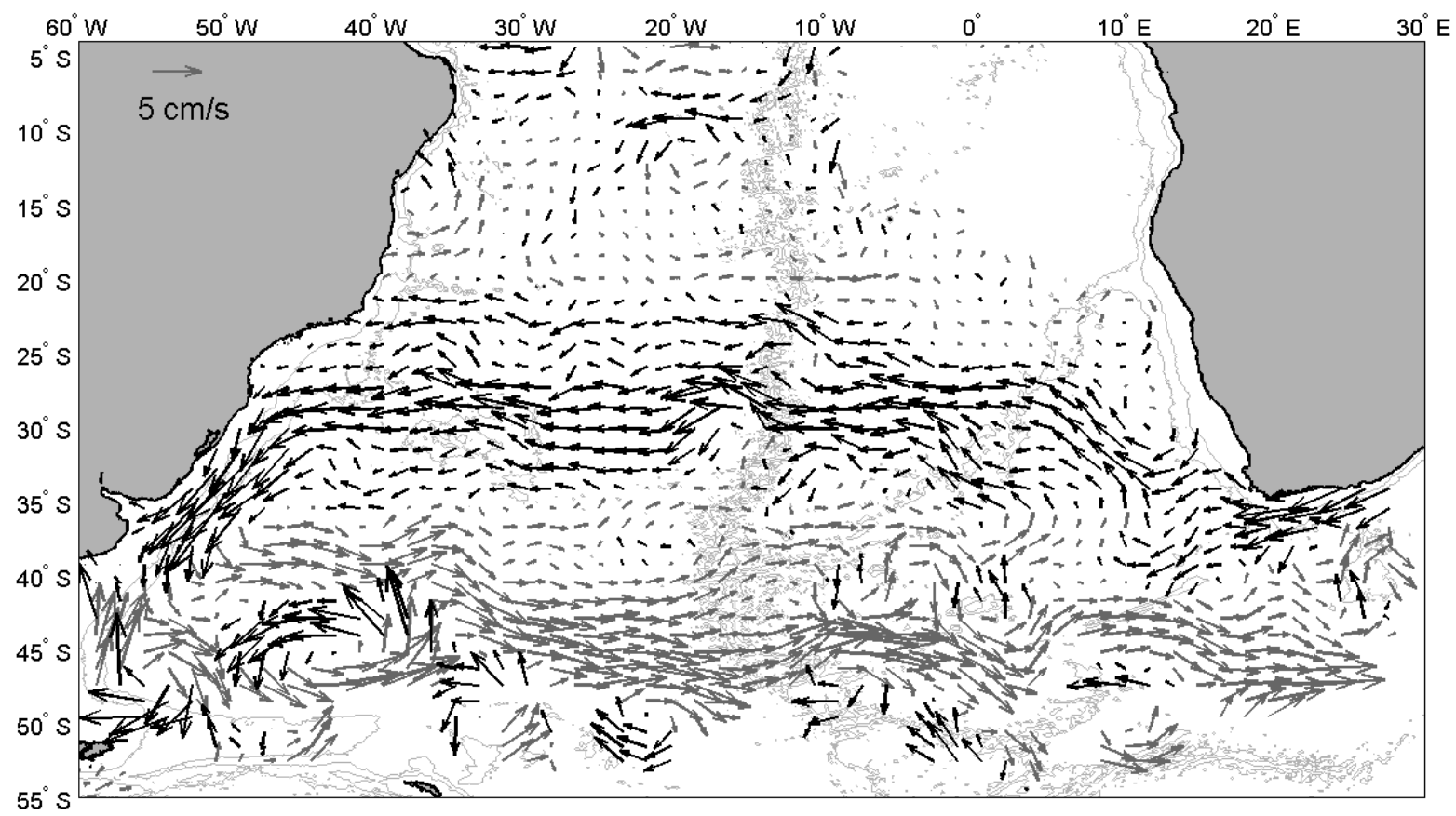

